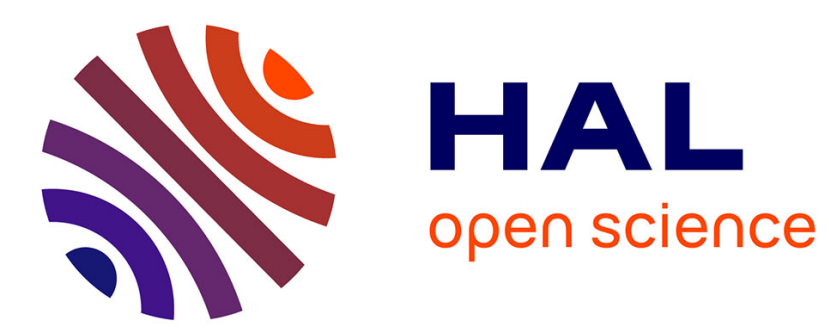

\title{
Country factors and the investment decision-making process of sovereign wealth funds
}

\author{
Jeanne J. Amar, B. Candelon, C. Lecourt, Z. Xun
}

\section{To cite this version:}

Jeanne J. Amar, B. Candelon, C. Lecourt, Z. Xun. Country factors and the investment decision-making process of sovereign wealth funds. Economic Modelling, 2019, 80, pp.34-48. 10.1016/j.econmod.2018.04.008 . hal-01897058

\section{HAL Id: hal-01897058 \\ https://hal-amu.archives-ouvertes.fr/hal-01897058}

Submitted on 30 Apr 2020

HAL is a multi-disciplinary open access archive for the deposit and dissemination of scientific research documents, whether they are published or not. The documents may come from teaching and research institutions in France or abroad, or from public or private research centers.
L'archive ouverte pluridisciplinaire HAL, est destinée au dépôt et à la diffusion de documents scientifiques de niveau recherche, publiés ou non, émanant des établissements d'enseignement et de recherche français ou étrangers, des laboratoires publics ou privés. 


\title{
Country factors and the investment decision-making process of sovereign wealth funds ${ }^{\text {is }}$
}

\author{
J. Amar ${ }^{\mathrm{a}}$, B. Candelon ${ }^{\mathrm{b}, \mathrm{c}}$, C. Lecourt ${ }^{\mathrm{d}}$, Z. Xun ${ }^{\mathrm{e}, *}$ \\ ${ }^{\text {a } A i x-M a r s e i l l e ~ U n i v e r s i t y, ~ C E R G A M ~ E A ~ 4225, ~ F r a n c e ~}$ \\ ${ }^{\mathrm{b}}$ Université Catholique de Louvain, Belgium \\ ${ }^{\mathrm{c}}$ Maastricht University, The Netherlands \\ d Aix-Marseille University, AMSE, France \\ e School of Economics, Jiangxi University of Finance and Economics, China
}

\begin{abstract}
A B S T R A C T
In this paper, we examine the complex decision-making processes that lead to sovereign wealth funds' (SWFs') choice of investment location. Using a two-tiered dynamic Tobit panel model, we find that country-level factors do not have the same impacts on the investment decision and the amount to invest and that SWFs tend to invest more frequently and at higher amounts in countries in which they have already invested. More specifically, we find that SWFs prefer to invest in countries with higher political stability, whereas they are more prone to invest large amounts in countries that are less democratic and more financially open. Our results also lend support to the idea that SWFs are prudent in their choice of a target country with regard to their investment decision but behave as more opportunistic investors with regard to the amounts to be invested.
\end{abstract}

Keywords:

Sovereign wealth funds

Targeted countries

Macroeconomic country factors

Two-tiered dynamic Tobit panel model

\section{Introduction}

Sovereign wealth funds (SWFs), "government-owned investment funds set up for a variety a macroeconomic purposes" (IMF (2008)), have received increasing attention since the late 2000s. Many countries have established SWFs for various macroeconomic purposes, such as stabilization, saving for future generations or investments in long-term economic projects (such as infrastructure or education). The assets managed by these funds, which are estimated at 7.3 trillion by the Sovereign Wealth Funds Institute in June 2017, have grown tremendously over the past decade, driven by high oil prices and current account surpluses, particularly in Asia. While the size and rapid growth of SWFs suggest that these funds have become major players in the finance world, buying large stakes in companies and giving governments exposure to sec- tors they may otherwise be unable to access, their objectives and behavior are not well understood. In particular, the opaqueness surrounding their structure and activities appear to be a major concern in host countries, for which it is unclear whether SWFs behave like governments or like institutional investors.

With the rapid expansion of sovereign wealth funds, financial economists have attempted to better understand the decisions made by this new class of investors. This task is not easy, as many SWFs are particularly opaque regarding their objectives and functioning. In addition, their investment decision-making process is complex because it combines several dimensions that can potentially interact. One of the main questions regarding SWFs' investment strategy is how they select countries and companies in which they invest. Are their investment strategies based only on financial motives, or

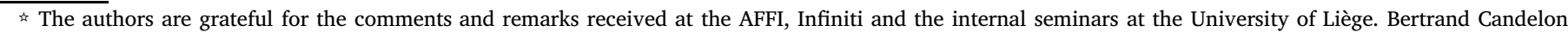

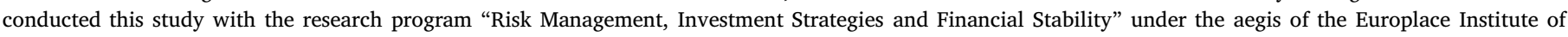
Finance and Insti7. The usual disclaimer applies.

* Corresponding author.

E-mail addresses: jeanne.amar01@gmail.com (J. Amar), candelonb@gmail.com (B. Candelon), christelle.lecourt@univ-amu.fr (C. Lecourt), decxun@hotmail. com (Z. Xun). 
are they also founded on macroeconomic, political or institutional considerations?

Most studies generally attempt to identify the main factors driving SWFs' investment decisions. Some papers assess whether these factors are macroeconomic (Ciarlone and Miceli (2014), Knill et al. (2012), or Megginson et al. (2013)) or political (Bernstein et al. (2013), Knill et al. (2012)). Other empirical studies also stress the link between the characteristics of the fund, such as its size, its degree of opacity, the origin of the funding (commodity versus non-commodity) and its investment decision (Knill et al. (2012), Avendano (2012), Megginson et al. (2013)). These studies conclude that SWFs' investments are influenced by the characteristics of the SWF and by those of the target countries.

Another dimension of SWF' investment decision-making process is the way they invest. In what type of firms will they prefer to invest, and what amount? Existing empirical studies dealing with this dimension have generally focused on the financial characteristics of the firm (for example, the firm's size and risk) as determinants of SWFs' investment strategy (see, for example, Kotter and Lel (2011)). In the same spirit, Johan et al. (2013) attempt to measure the choice of SWFs for investing in public versus private global firms and show that SWFs are more likely to invest in private firms in countries that have less-developed legal systems.

In line with this existing literature, the aim of this paper is to better understand the decision-making process that leads to the choice of investment locations by this new class of investors. More specifically, we attempt to explain SWFs' motivation to invest in a particular country by considering the geographic, economic, political and institutional distances between the acquiring and target countries. Using a new database for the recent period 2000-2014, we examine 609 foreign equity investments made by 29 SWFs from 15 countries in 72 target countries. Based on the recent paper by Xun and Lubrano (2016), we adopt a sophisticated two-tiered dynamic panel Tobit model to jointly estimate the decision to invest and the amounts to be invested. The dynamic dimension in the panel model allows us to estimate whether SWFs tend to invest more frequently and at higher amounts in countries in which they already have invested.

Anticipating on our findings, we find that SWFs' investments are driven by country-level factors. This paper also shows that the determinants of the investment decision are different from those driving the amount of investment, motivating the use of the two-tiered Tobit panel model to investigate this issue. In particular, our results lend support to the idea that SWFs are prudent in the choice of target country with regard to their investment decision but behave as more opportunistic investors with regard to the amounts to be invested. Ultimately, our findings exhibit a persistence in SWF investment strategy, which means that SWFs have a tendency to invest again in the target country once the decision to invest has been taken.

The paper is organized as follows. Section 2 introduces the theoretical framework and the hypotheses for analyzing SWFs' investment decisions abroad. Section 3 provides details on the data. Section 4 presents the econometric methodology, Section 5 reports our empirical findings, and Section 6 concludes.

\section{Theoretical framework and empirical hypotheses}

Extensive recent literature investigates the potential factors driving SWF investment decisions. In particular, because they are state-owned investment funds that may be managed either by the ministry of finance or by a board composed of government officials, SWFs' investment strategy may be not only commercially oriented but also politically biased. We report this literature and show how it opens pathways for new research on the identification of SWFs' investment determinants.

H1. SWFs tend to invest in countries that share the same macroeconomic, geographical, political and institutional characteristics as the home country.
Most of the literature studying SWFs addresses the main concern raised by these investors: is SWFs' investment strategy guided by purely financial motives, or is it biased by more strategic objectives? In order to answer this question, a large section of the literature has attempted to identify the main drivers of SWF investments.

Even if certain authors show that firm-level characteristics influence SWFs' investment decisions (see, among others, Kotter and Lel (2011) or Avendano (2012)), a large portion of the literature shows that SWFs' investment decisions are driven mostly by country factors. More specifically, relying on the literature on Foreign Direct Investments (FDI), certain papers test whether SWFs are more likely to invest in countries that are similar to their home countries in terms of culture, economic development or political institutions. Chhaochharia and Laeven (2009) and Megginson et al. (2013) show that SWFs prefer to invest in countries with which they share the same culture (in terms of language or religion). For other variables, results are more divergent. Megginson et al. (2013) find that SWFs are more prone to invest in countries that are trade partners, whereas Chhaochharia and Laeven (2009) find opposing results. Knill et al. (2012) show that SWFs prefer to invest in countries that are close (in terms of geographic distance), while Megginson et al. (2013) find that geographic proximity does not explain SWFs' investment decisions. Finally, Knill et al. (2012) conclude that SWFs are more likely to invest in countries with which they have weak political bilateral relations.

Although the existing literature finds evidence that country factors matter in SWFs' investment decision-making process, there is a lack of consensus regarding the determinants of their investment strategy. The great heterogeneity among SWFs, the unavailability of data on some of their transactions and specification problems can explain the variation in these results.

Relying on the empirical literature on Foreign Direct Investments (FDIs) (see, among others, Anderson and Van Wincoop (2003), Stulz and Williamson (2003) and Kang and Kim (2008)), we expect that SWFs will prefer to invest in regions or countries in which they have either an information advantage or perceived familiarity in terms of cultural, institutional or macroeconomic characteristics.

In the same way, we predict that geographic proximity will be associated with more investment deals between both countries.

H2. Target country factors do not have the same impacts on the investment decision and the amount to invest.

Note that $\mathrm{H} 1$ does not provide information on the way SWFs will invest. Once the decision of whether or not to invest in a given country has been made based on country-level factors, SWFs decide the amount to be invested. In line with Knill et al. (2012), we consider SWFs' complex decision-making process by specifying two stages. In the first stage, the SWF chooses the country in which it will invest. In the second stage, the SWF decides how much it will invest. Ignoring the two-stage nature of the investment decision assumes that country factors have the same impact during both stages. We expect that country-level factors' impact on the investment decision differs from that on the amount of the investment.

H3. SWFs tend to invest more frequently and at higher amounts in countries in which they have already invested.

Related to H1, if a SWF chooses to invest in a country that shares similar characteristics in terms of macroeconomic, political, institutional or cultural factors, it will likely continue to invest in this country in the future because it is already informed about this target country. In this way, it avoids search and informational costs of investing in this country. Therefore, we test whether there is a learning effect in the SWF investment decision-making process. If so, once an investment decision is taken, the SWF will likely keep investing in the same country in the future. 


\section{Data and descriptive analysis}

\subsection{The SWF sample}

In both the academic and the practitioner literature, there is no consensus on exactly what an SWF is. A unanimously accepted definition is that given by the International Monetary Fund (IMF (2008)), according to which "SWFs are government-owned investment funds established for a variety a macroeconomic purposes". Considering the lack of consensus on the definition of an SWF and the lack of transparency in the methodologies used in the existing empirical literature to collect data, we have decided to construct a unique database from scratch using the following methodology.

Considering this definition, we conducted a search of all existing SWFs by using different sources in order to have the most complete list. We begin with a preliminary sample of SWFs given on the SWF Institute website ${ }^{2}$ by combining the names of funds published by JP Morgan (Fernandez and Eschweiler (2008)), Catalano (2009), Lyons (2007) and the SWFs' websites. When different names for the same SWF are found, we employ the fund's websites to eliminate duplicates. Moreover, we consider a fund to be active if it has made at least one publicly reported investment internationally. Because many funds have been created and announced on the websites but are not active, this search yields a sample of 89 existing SWFs in 2013, but only 29 of these funds from 15 countries are retained for the analysis. ${ }^{3}$ Details on these 29 funds are presented in Appendix 1.

\subsection{Investment data}

We construct our sample of SWFs' investments in listed firms using two different sources. First, we search the financial database Thomson Reuters Eikon Mergers and Acquisitions for all known SWFs and their subsidiaries in order to identify transactions involving SWFs. Second, we use the online database Factiva to complete the missing acquisitions. Investment data are extracted for both the SWFs and their wholly owned subsidiaries. ${ }^{4}$ The features of each transaction are collected: information about the targeted firms (name and country), information about the SWFs (name, subsidiary, and country), the date of the transaction, the pre- and post-acquisition shares of the investment in the target firm and the value of the deal.

Table 1 presents summary statistics - overall and by year - for the number and total value of cross-border SWF deals. The combined sample for both sources from 2000 to 2013 allows us to capture 609 crossborder acquisitions by 29 SWFs with a total value of USD 278,406 million. ${ }^{5}$ As described in Table 1 , SWFs made an increasing number of cross-border investments between 2005 and 2007, driven by fast-growing influxes of revenue combined with the search for better returns. The number of cross-border investments reached a peak in 2007, with 118 investments representing approximately $19 \%$ of the

\footnotetext{
${ }^{1}$ For example, the Sovereign Investor Institute's Sovereign Wealth Center includes 32 funds in its database, whereas the SWF Institute retains 78 SWFs.

2 http://www.swfinstitute.org/.

${ }^{3}$ Because our analysis focuses on the investment amounts, we retain only cross-border transactions for which the deal value is available.

4 The newswires cited above report information regarding the name of the fund, the name of the subsidiary, the name of the target firm and the size of the stake.

5 Through open market share purchases, Norway's Government Pension Fund Global (GPFG) acquired many small stakes in listed companies during the considered period (more than 55,000 investments with a stake size of less than $2 \%$ ). For this reason, we choose to remove it from the database. All the investments and their market value are given by Norway's Government Pension Fund Global on its website: http://www.nbim.no/en/Investments/holdings.
}

total number of foreign transactions over the $2000-2013$ period. ${ }^{6}$ During the crisis, many funds shifted their investment strategies, retreating from foreign markets and increasing their domestic investments. The number of foreign investments sharply dropped in 2008, even though the volume of investment activity remained substantially high (the total value of SWF investments in 2008 represents $21.1 \%$ of the total value of SWF investments over the 2000-2013 period). In the past few years, SWFs have continued to actively invest abroad, with 136 transactions completed in 2012-2013.

Table 2 presents the distribution of cross-border investments made by SWFs of 15 countries in terms of their value and number and shows that the majority of the most active SWFs are located in Asia and in the Middle East. Singapore made more cross-border investments than any other country (265 foreign deals, which represents $43.5 \%$ of all SWF investments by number and $36.07 \%$ by value), followed by SWFs from the United Arab Emirates (21.8\% of deals, $30.8 \%$ of value), ${ }^{7}$ Qatar (14.3\% of deals, $12.07 \%$ of value) and China ( $7.1 \%$ of deals, $12.4 \%$ of value). We observe that funds from Kuwait made few investments compared to the others ( $2.3 \%$ of deals) but did so at large amounts (4.43\% of all investments by value).

Finally, Table 3 outlines the geographical distribution of SWF country investments by number (Panel A) and by value (Panel B) in target firm regions. The clear trend revealed by this table is SWFs' preference to invest in the developed countries of North America $(18.23 \%$ of total deals, $27.63 \%$ of value) and Western Europe (26.6\% of total deals, $32.91 \%$ of value), particularly in the English common law countries of Canada, the United States and Great Britain. This trend is clearly the case for SWFs from the United Arab Emirates, Qatar, China and, to a lesser extent, Singapore, which have invested (in number and in value) in both regions over this period. The other target regions are the Far East (14.78\% of total deals, $9.33 \%$ of value) and the Indian Subcontinent (13.63\% of total deals, $6.12 \%$ of value). The fact that the majority of SWF investments are targeted towards developed countries with safe institutions, high revenues and financial regulations reveal that macroeconomic factors matter for their investment decisions. Less clearly, this picture reveals a tendency for SWFs to invest in their own geographical region. More precisely, SWFs from the Middle East and South Asia also prefer to invest in their own geographical region even if they seem to have a strategy of geographical diversification. Note that geographical diversification of SWF cross-border investments is sometimes very different in number and in amounts, which suggests that the SWF decision to invest in a particular country and the decision regarding the amount to invest in this country are not based on the same criteria. A revealing example is the only stake in Central and South America purchased by the fund of Qatar amounted to an impressive USD 2716 million. ${ }^{8}$

\section{Methodology: the two-tiered dynamic Tobit panel model}

In this paper, we estimate a two-tiered dynamic Tobit panel model developed by Chang (2011b) and improved by Xun and Lubrano (2016). The choice of this model offers many advantages to better evaluate the decision-making process that leads to SWFs' investment location. First, the "two-tiered" dimension allows a distinction between the decision to invest and how much the SWF invests. Second, the SWF decision to invest in a particular country may also be persistent over time. It means that if a first investment has been made in year

\footnotetext{
${ }^{6}$ In 2007, SWFs emerged as major players on the world financial markets; in particular, they pumped USD 60 billion into Western banks during the financial meltdown.

7 The Abu Dhabi Investment Authority (ADIA) is considered the second biggest fund.

${ }^{8}$ Qatar Holding invested USD 2716 million in Banco Santander Brazil, which represents $5 \%$ of stakes.
} 
Table 1

Annual distribution of SWFs' foreign investments. This table presents the number of deals and the total deal value of cross-border investments led by SWFs (excluding Norway) by year. Column 3 provides the proportion of the number of SWF investments made in year $t$ among all investments made over the 2000-2013 period. Column 5 shows the proportion of the value of SWF investments made in year $t$ among the total value of SWFs' foreign investments over the $2000-2013$ period.

\begin{tabular}{llll}
\hline Year & Number of foreign investments & Proportion (Number of deals) & Total value of foreign investments (USD million) \\
\hline 2000 & 17 & $2.8 \%$ & 3665.9 \\
2001 & 4 & $0.7 \%$ & 9260.7 \\
2002 & 8 & $1.3 \%$ & 898.9 \\
2003 & 13 & $2.1 \%$ & 2713.3 \\
2004 & 13 & $2.1 \%$ & 5108 \\
2005 & 42 & $6.9 \%$ & 11,727 \\
2006 & 87 & $14.3 \%$ & $20,885.3$ \\
2007 & 118 & $19.4 \%$ & $43,302.7$ \\
2008 & 36 & $5.9 \%$ & $58,860.4$ \\
2009 & 34 & $5.6 \%$ & $21,415.4$ \\
2010 & 60 & $9.9 \%$ & $24,911.5$ \\
2011 & 41 & $6.7 \%$ & $28,238.2$ \\
2012 & 94 & $15.4 \%$ & $32,539.1$ \\
2013 & 42 & $6.9 \%$ & $14,880.3$ \\
Total & 609 & $100 \%$ & $278 \%$ \\
\hline
\end{tabular}

Table 2

Geographic distribution of SWFs' foreign investments - Acquirer countries. This table presents the number of deals and the total deal value of cross-border investments led by SWFs by country (excluding Norway) over the 2000-2013 period. Column 3 shows the proportion of the number SWF investments made by

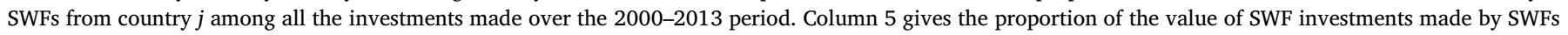
from country $j$ among the total value of SWF foreign investments over the 2000-2013 period.

\begin{tabular}{|c|c|c|c|c|}
\hline & Number of foreign investments & Proportion (Number of deals) & Total value of foreign investments (USD million) & Proportion (Amount) \\
\hline Australia & 4 & $0.7 \%$ & 477.8 & $0.17 \%$ \\
\hline Bahrain & 1 & $0.2 \%$ & 46.0 & $0.02 \%$ \\
\hline China & 43 & $7.1 \%$ & $34,521.9$ & $12.4 \%$ \\
\hline France & 2 & $0.3 \%$ & 167 & $0.06 \%$ \\
\hline Kazakhstan & 2 & $0.3 \%$ & 299.1 & $0.11 \%$ \\
\hline Kuwait & 14 & $2.3 \%$ & $12,340.8$ & $4,43 \%$ \\
\hline Libya & 7 & $1.1 \%$ & 1054.3 & $0.38 \%$ \\
\hline Malaysia & 25 & $4.1 \%$ & 5108.7 & $1.83 \%$ \\
\hline New Zealand & 3 & $0.5 \%$ & 184.7 & $0.07 \%$ \\
\hline Oman & 16 & $2.6 \%$ & 1916.3 & $0.69 \%$ \\
\hline Qatar & 87 & $14.3 \%$ & $33,600.9$ & $12.07 \%$ \\
\hline Saudi Arabia & 4 & $0.7 \%$ & 376.2 & $0.14 \%$ \\
\hline Singapore & 265 & $43.5 \%$ & $100,422.4$ & $36.07 \%$ \\
\hline South Korea & 3 & $0.5 \%$ & 2146.5 & $0.77 \%$ \\
\hline UAE & 133 & $21.8 \%$ & $85,744.2$ & $30.8 \%$ \\
\hline Total, excluding Norway & 609 & $100 \%$ & $278,406.7$ & $100 \%$ \\
\hline
\end{tabular}

$t$, intimacy links are created, the SWF will likely invest in this country again in the future. Therefore, the dynamic component is included via an autoregressive term in the first and second decisions. Finally, unlike Knill et al. (2012), who estimate a Cragg model with crosssectional data, we consider a panel dimension in the model in order to take into account two central aspects: i) the temporal dimension that is necessary to explain the number of SWFs' cross-border investments by year in our sample; and ii) the unobserved heterogeneity between the different SWFs. This hypothesis is fundamental because SWFs form a heterogeneous group of investors, explained with respect to the various sources of their funds, their size in terms of assets under management, their organizational structure, their governance and their assigned objectives. In the same way, the inclusion of individual random effects in the panel model allows us to control for omitted variables.

Before describing the two-tiered dynamic Tobit panel model, let us consider the one-tiered dynamic Tobit model for panel data and autocorrelated errors developed by Chang (2011a), which is written as

$y_{i t}^{*}=x_{i t} \beta+y_{i t-1} \lambda+\epsilon_{i t}$,

$y_{i t}=\max \left(y_{i t}^{*}, 0\right)$ where $y_{i t}^{*}$ is a latent dependent variable, $x_{i t}$ a vector of exogenous variables, $y_{i t}$ an observed dependent variable and $\epsilon_{i t}$ an idiosyncratic error that varies across time and individuals. The error term is assumed to have the following structure:

$\epsilon_{i t}=c_{i}+v_{i t}$,

$v_{i t}=\zeta v_{i, t-1}+u_{i t}$,

where $c_{i} \sim N\left(0, \sigma_{d}\right)$ is an unobserved individual random effect that is constant over time and $u_{i t} \sim N\left(0, \sigma_{u}\right)$ is an idiosyncratic error that varies across time and individuals. $\zeta$ is the auto-correlation parameter of the error terms. The stationary assumption $|\zeta|<1$ is assumed to be satisfied for the random effects plus AR(1) errors model. ${ }^{9}$

One potential restriction of traditional Tobit models lies in the fact that the decision related to $y=0$ versus $y>0$ is inseparable from the decision concerning the amount of $y$, given that $y>0$. In order to relax this restriction, Cragg (1971) proposed a two-tiered model to allow the parameters that characterize the decision regarding $y>0$ versus $y=0$

\footnotetext{
${ }^{9}$ See Chang (2011a) for details on the simulation estimation of this model.
} 
Table 3

Geographical distribution of SWF foreign investments - Targeted countries. This table presents the number and value of cross-border investments made by SWFs originating from country $j$ to target firms in region $k$ over the 2000-2013 period. Panel A gives the number of deals, while Panel B gives the total amount invested in USD billion.

\begin{tabular}{|c|c|c|c|c|c|c|c|c|c|c|c|c|c|c|c|}
\hline \multirow[t]{2}{*}{ SWF countries } & \multicolumn{15}{|c|}{ Target firm regions } \\
\hline & Africa & $\begin{array}{l}\text { Caribbean } \\
\text { West indies }\end{array}$ & $\begin{array}{l}\text { Central \& South } \\
\text { America }\end{array}$ & $\begin{array}{l}\text { Central } \\
\text { Asia }\end{array}$ & $\begin{array}{l}\text { Central } \\
\text { Europe }\end{array}$ & $\begin{array}{l}\text { East } \\
\text { Europe }\end{array}$ & $\begin{array}{l}\text { Far } \\
\text { East }\end{array}$ & $\begin{array}{l}\text { Indian } \\
\text { Subcontinent }\end{array}$ & $\begin{array}{l}\text { Middle } \\
\text { East }\end{array}$ & $\begin{array}{l}\text { North } \\
\text { America }\end{array}$ & $\begin{array}{l}\text { North } \\
\text { Europe }\end{array}$ & $\begin{array}{l}\text { Oceanic } \\
\text { Basin }\end{array}$ & $\begin{array}{l}\text { South East } \\
\text { Asia }\end{array}$ & $\begin{array}{l}\text { West } \\
\text { Europe }\end{array}$ & Total \\
\hline \multicolumn{16}{|c|}{ Panel A: Number of Investments } \\
\hline Australia & 0 & 0 & 0 & 0 & 0 & 0 & 0 & 0 & 0 & 0 & 0 & 0 & 0 & 4 & 4 \\
\hline Bahrain & 0 & 0 & 0 & 0 & 0 & 0 & 0 & 0 & 0 & 0 & 0 & 0 & 0 & 1 & 1 \\
\hline China & 8 & 1 & 1 & 7 & 0 & 0 & 2 & 0 & 0 & 12 & 0 & 4 & 2 & 6 & 43 \\
\hline France & 0 & 0 & 0 & 0 & 0 & 0 & 0 & 0 & 0 & 2 & 0 & 0 & 0 & 0 & 2 \\
\hline Kazakhstan & 0 & 0 & 0 & 0 & 0 & 0 & 0 & 0 & 1 & 0 & 0 & 0 & 0 & 1 & 2 \\
\hline Kuwait & 0 & 0 & 0 & 0 & 0 & 0 & 3 & 2 & 2 & 5 & 0 & 0 & 0 & 2 & 14 \\
\hline Libya & 1 & 0 & 0 & 1 & 0 & 0 & 0 & 0 & 0 & 1 & 0 & 0 & 0 & 4 & 7 \\
\hline Malaysia & 0 & 0 & 0 & 0 & 0 & 0 & 5 & 7 & 4 & 0 & 0 & 0 & 9 & 0 & 25 \\
\hline New Zealand & 0 & 0 & 0 & 0 & 0 & 0 & 1 & 0 & 0 & 2 & 0 & 0 & 0 & 0 & 3 \\
\hline Oman & 0 & 0 & 0 & 0 & 0 & 1 & 0 & 7 & 1 & 0 & 0 & 1 & 2 & 4 & 16 \\
\hline Qatar & 0 & 0 & 1 & 0 & 0 & 0 & 1 & 4 & 2 & 7 & 1 & 0 & 2 & 69 & 87 \\
\hline Saudi Arabia & 1 & 0 & 0 & 0 & 0 & 0 & 0 & 0 & 1 & 1 & 0 & 0 & 0 & 1 & 4 \\
\hline Singapore & 3 & 0 & 5 & 2 & 1 & 0 & 73 & 53 & 0 & 49 & 2 & 21 & 28 & 28 & 265 \\
\hline South Korea & 0 & 0 & 0 & 0 & 0 & 0 & 0 & 0 & 0 & 3 & 0 & 0 & 0 & 0 & 3 \\
\hline UAE & 4 & 0 & 4 & 0 & 2 & 0 & 5 & 10 & 10 & 29 & 5 & 6 & 16 & 42 & 133 \\
\hline Total & 17 & 1 & 11 & 10 & 3 & 1 & 90 & 83 & 21 & 111 & 8 & 32 & 59 & 162 & 609 \\
\hline Proportion & $2.79 \%$ & $0.16 \%$ & $1.81 \%$ & $1.64 \%$ & $0.49 \%$ & $0.16 \%$ & $14.78 \%$ & $13.63 \%$ & $3.45 \%$ & $18.23 \%$ & $1.31 \%$ & $5.25 \%$ & $9.69 \%$ & $26.60 \%$ & $100 \%$ \\
\hline \multicolumn{16}{|c|}{ Panel B: Value of Investments } \\
\hline Australia & 0 & 0 & 0 & 0 & 0 & 0 & 0 & 0 & 0 & 0 & 0 & 0 & 0 & 478 & 478 \\
\hline Bahrain & 0 & 0 & 0 & 0 & 0 & 0 & 0 & 0 & 0 & 0 & 0 & 0 & 0 & 46 & 46 \\
\hline China & 1258.5 & 850 & 200 & 6622 & 0 & 0 & 1263 & 0 & 0 & 15,988 & 0 & 1,1670 & 1004 & 6167 & 34,522 \\
\hline France & 0 & 0 & 0 & 0 & 0 & 0 & 0 & 0 & 0 & 167 & 0 & 0 & 0 & 0 & 167 \\
\hline Kazakhstan & 0 & 0 & 0 & 0 & 0 & 0 & 0 & 0 & 166 & 0 & 0 & 0 & 0 & 133 & 299 \\
\hline Kuwait & 0 & 0 & 0 & 0 & 0 & 0 & 981 & 3600 & 117 & 6450 & 0 & 0 & 0 & 1194 & 12,341 \\
\hline Libya & 44.8 & 0 & 0 & 300 & 0 & 0 & 0 & 0 & 0 & 320 & 0 & 0 & 0 & 390 & 1054 \\
\hline Malaysia & 0 & 0 & 0 & 0 & 0 & 0 & 353 & 603 & 730 & 0 & 0 & 0 & 3423 & 0 & 5109 \\
\hline New Zealand & 0 & 0 & 0 & 0 & 0 & 0 & 1.8 & 0 & 0 & 183 & 0 & 0 & 0 & 0 & 185 \\
\hline Oman & 0 & 0 & 0 & 0 & 0 & 129 & 0 & 434 & 79 & 0 & 0 & 2.5 & 86 & 1187 & 1916 \\
\hline Qatar & 0 & 0 & 2719 & 0 & 0 & 0 & 78 & 800 & 247 & 1958 & 44 & 0 & 2389 & 25,366 & 33,601 \\
\hline Saudi Arabia & 7625 & 0 & 0 & 0 & 0 & 0 & 0 & 0 & 155 & 200 & 0 & 0 & 0 & 154 & 376 \\
\hline Singapore & 2693 & 0 & 1010 & 412 & 43 & 0 & 21,701 & 6000 & 0 & 24,268 & 360 & 16,683 & 4256 & 22,995 & 100,422 \\
\hline South Korea & 0 & 0 & 0 & 0 & 0 & 0 & 0 & 0 & 0 & 2147 & 0 & 0 & 0 & 0 & 2147 \\
\hline UAE & 6 & 0 & 750 & 0 & 361 & 0 & 1591 & 5598 & 930 & 25,249 & 6126 & 3402.9 & 8212 & 33,518 & 85,744 \\
\hline Total & 4010 & 850 & 4679 & 7335 & 404 & 128 & 25,967 & 17,035 & 2283 & 76,929 & 6531 & 21,258 & 19,369 & 91,625 & 278,406 \\
\hline Proportion & $1.44 \%$ & $0.31 \%$ & $1.68 \%$ & $2.63 \%$ & $0.15 \%$ & $0.05 \%$ & $9.33 \%$ & $6.12 \%$ & $0.82 \%$ & $27.63 \%$ & $2.35 \%$ & $7.64 \%$ & $6.96 \%$ & $32.91 \%$ & $100 \%$ \\
\hline
\end{tabular}


to be distinct from the parameters that determine the decision regarding the amount of $y$, given that $y>0$. We can say that traditional Tobit models can be viewed as a special case of Cragg's two-tiered model. It means that Cragg's two-tiered model is based on two assumptions. First, a probit model provides the probability of a zero observation with the first-tier parameters and then the density of the dependent variable that is conditional on being a positive observation is truncated at zero and characterized by the second-tier parameters. Second, Cragg's model can be extended from the cross-sectional framework to the dynamic panel data models using the simulation estimators proposed by Chang (2011b) and Xun and Lubrano (2016). Therefore, the two-tiered Tobit model is more efficient and provides a more flexible specification than the standard Tobit models. ${ }^{10}$

In our specification, if we consider $y_{i j, t}$ to be an observed dependent variable representing the average amount (in USD) of investments in country $i$ from SWFs in country $j$ in year $t$, the SWFs' investment since they are not random, and considering them as exogenous might cause endogeneity problems. To deal with this problem, Chang (2011b) proposes a maximum simulated likelihood procedure through the correlated random effects approach for the two-tiered dynamic Tobit model using the Geweke-Hajivassiliou-Keane (GHK) simulator. In a very recent paper, Xun and Lubrano (2016) show, however, that the use of Heckman's initial conditions combined with latent state dependence leads to computational difficulties and an incorrect specification of the true state dependence. Thus, they propose to follow the treatment of initial values proposed by Wooldridge (2005). We consider a two-tiered dynamic Tobit panel model initiated by Chang (2011a,b) and completed by Xun and Lubrano (2016).

We then construct the truncated normal random variables $\eta_{i j, t}^{r}$ for censored and uncensored events that can be simulated from, respectively, ${ }^{12}$

$\eta_{i j, t}^{r}=\left\{\begin{array}{l}\Phi^{-1}\left(\xi_{i t}^{r} \Phi\left(\frac{-x_{i j, t}^{\prime} \beta^{1}-y_{i j, t-1} \lambda_{1}^{1} I_{i j, t}\left(y_{i j, t-1}>0\right)-\lambda_{2}^{1} I_{i j, t}\left(y_{i j, t-1}=0\right)-c_{i j}^{1}-\sum_{k=1}^{t-1} A_{t k} \eta_{i j, k}^{r}}{A_{t t}}\right)\right) \\ \frac{y_{i j, t}-x_{i j, t}^{\prime} \beta^{2}-y_{i j, t-1} \lambda_{1}^{2} I_{i j, t}\left(y_{i j, t-1}>0\right)-\lambda_{2}^{2} I_{i j, t}\left(y_{i j, t-1}=0\right)-c_{i j}^{2}-\sum_{k=1}^{t-1} A_{t k} \eta_{i j, k}^{r}}{A_{t t}}\end{array}\right)$

decision should be considered as a two-step process: the first step is a binary decision, either $y_{i j, t}>0$ or $y_{i j, t}=0 .{ }^{11}$ In the second step, which occurs once the green light for the investment has been given, the SWF decides the amount to be invested in the specific country. Fig. 1 illustrates the SWF investment decision-making process that is considered
We can then simulate the $\mathrm{r}^{\text {th }}$ event probabilities for pair $i j$ at period $t$ recursively by using the previous periods' event simulations $\eta_{i j, t-k}^{r}$ as given conditional information:

$$
\left\{\begin{array}{l}
P^{r}\left(I_{i j, t}=1 \mid y_{i j, t-1}\right)=\Phi\left(\frac{x_{i j, t}^{\prime} \beta^{1}+y_{i j, t-1} \lambda_{1}^{1} I_{i j, t}\left(y_{i j, t-1}>0\right)+\lambda_{2}^{1} I_{i j, t}\left(y_{i j, t-1}=0\right)+c_{i j}^{1}+\sum_{k=1}^{t-1} A_{t k} \eta_{i j, k}^{r}}{A_{t t}}\right) \\
f^{r}\left(y_{i j, t} \mid y_{i j, t-1}\right)=\frac{1}{A_{t t}} \phi\left(\frac{y_{i j, t}-x_{i j, t}^{\prime} \beta^{2}-y_{i j, t-1} \lambda_{1}^{2} I_{i j, t}\left(y_{i j, t-1}>0\right)-\lambda_{2}^{2} I_{i j, t}\left(y_{i j, t-1}=0\right)-c_{i j}^{2}-\sum_{k=1}^{t-1} A_{t k} \eta_{i j, k}^{r}}{A_{t t}}\right)
\end{array}\right.
$$

in a two-tiered model.

Taking into account the rich dynamic structure of the model allows us to test the persistence phenomenon in the investment decision process, i.e., the fact that SWFs may invest again and for the same amounts in the same target country in the following years once the decision to invest has been taken. The introduction of lagged dependent variables and serially correlated errors in a dynamic panel Tobit model has the effect of making the conventional estimation techniques used in the panel data models inapplicable. Chang (2011b) proposes to estimate the dynamic Tobit panel model with the random effects approach. The random effects estimators are obtained by maximizing the corresponding likelihood function by specifying the distribution of the error conditional on the regressors. However, the dimension of the integral involved in the calculation of the likelihood function of the dynamic Tobit model, which is as large as the number of censoring periods in the model, makes this likelihood function usually intractable. Taking the initial conditions into account is essential in the dynamic analysis

\footnotetext{
10 An alternative to the two-tiered model is the Heckman (1979) type of sample selection model. See the discussion in Chang (2011b) for the difference between both models.

11 We use the average amounts (in USD) of investments in country $i$ from SWFs in country $j$ in year $t$ as the dependent variable rather than total amounts for two reasons: i) first, certain countries have more than one SWF, and in this case, we take the average amount of investments made in country $j$ by all SWFs in country $i$ for each year; ii) taking the average amounts of investments allow us to control for the number of investments. Making a large number of small investments is different from making only one large investment.
}

for occurrence event and amount event probability, respectively. Additionally, we assume that the latent variable $y_{i j, t}^{*}$ can be modelled as

$y_{i j, t}^{*}=x_{i j, t}^{\prime} \beta+y_{i j, t-1} \lambda_{1} I_{i j, t}\left(y_{i j, t-1}>0\right)+\lambda_{2} I_{i j, t}\left(y_{i j, t-1}=0\right)+c_{i j}+v_{i j, t}$

with $I_{i j, t}$ the indicator function defined as

$I_{i j, t}= \begin{cases}1 & \text { when } y_{i j, t}>0 \\ 0 & \text { otherwise }\end{cases}$

For pair $i j, I_{i j, t}=1$ if the observed value $y_{i j, t}$ is non-zero. In contrast, $I_{i j, t}=0$ if $y_{i j, t}$ is censored.

In this specification, the two-tiered structure implies that the probability of the investment decision $\operatorname{Prob}\left(y_{i j, t}^{*}\right)>0$ is computed with a first set of parameters $\left(\beta^{1}, \lambda_{1}^{1}, \lambda_{2}^{1}, c_{i j}^{1}\right)$, while the amount to be invested (i.e., the conditional expectation of $y_{i j, t}$ ), given that the investment decision is determined by a second set of parameters $\left(\beta^{2}, \lambda_{1}^{2}, \lambda_{2}^{2}, c_{i j}^{2}\right)$. As already stated, we can observe in this specification that the twotiered Tobit model allows us to identify in the same model both the

\footnotetext{
12 where $r$ means $\mathrm{r}^{\text {th }}$ simulation, $\eta \sim N(0,1), \xi$ is drawn from uniform $(0,1)$ for $\mathrm{R}$ times once and fixed during the MLE process, $\Phi$ and $\phi$ refer to the CDF and PDF of standard normal density, respectively, A is the lower triangular matrix obtained from the Cholesky decomposition of the compounded errors (individual random effect $+\mathrm{AR}(1)$ ).
} 


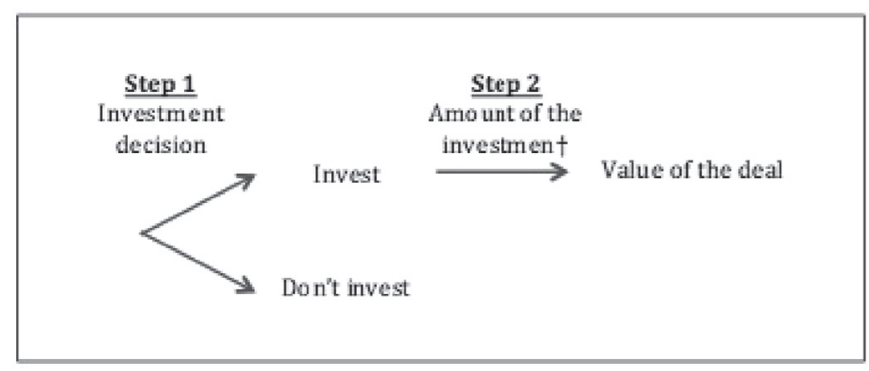

Fig. 1. SWF investment decision-making process.

determinants of the investment decision and the determinants of the amount to be invested, unlike a simple Tobit model. The choice of this model is therefore justified to test for H2. It must be noted that we include the same explanatory variables in each step of the two-tiered model.

Because we have two equations and make a distinction between censored and uncensored events, we have four different values for the $\lambda s$ when using Wooldridge's specification for the initial values. ${ }^{13}$ These four parameters indicate the persistence of the investment decision and the amount invested, respectively. Similar to the standard Tobit model, all the other parameters $\left(\zeta, \sigma_{u}\right.$ and $\sigma_{d}$, which are, respectively, the error variances of $u_{i j, t}$ and $d_{i j}$ [an individual random effect that is unchanged for pair $i j$ across the panel period $t$ ] and follow a Normal distribution with zero mean) are common to both steps. ${ }^{14}$

\section{Empirical part}

\subsection{Description of the macroeconomic variables}

The two-tiered dynamic Tobit panel model described above is estimated for a large set of explanatory variables that cover the macroeconomic, geographic, financial, institutional and cultural sectors. The selected macroeconomic variables are the annual GDP growth rate $(G D P)$, the inflation rate (INFLATION) and the real effective exchange rate returns $(R E E R)$. As a financial variable, we consider the ChinnIto index (KAOPEN), which measures the country's degree of capital account openness. Institutional variables measuring the level of political risk are corruption (CORRUPTION) and government stability (GOV STAB). ${ }^{15}$ POLITY is the difference in democracy levels between the SWF country and target country, as defined by the polity IV database. RELIGION is a dummy variable equal to one if the nations have the same major religion, and zero otherwise. DIST is a variable measuring the geographic distance between the acquiring and target country. As in Karolyi and Liao (2017) and Knill et al. (2012), we use for these variables the difference between the SWF and the target nation. Analyzing country-pairs is necessary to calculate the bilateral "difference" between explanatory variables and the dependent variable. We test whether geographic distance and variables illustrating that economic and institutional distance are determinants of SWF investment deci-

\footnotetext{
${ }^{13}$ The interpretations of the true state dependence terms are straightforward: they control for the previous state's level of dependency (depending on whether it was an occurred event $I\left(y_{i, t-1}>0\right)$ or a null event $I\left(y_{i, t}-1=0\right)$, since an occurred event and a null event have different natures and different recorded scaling) on the current state.

14 Other details of the model are given in Appendix 3.

${ }^{15}$ As GOV STAB represents the government's ability to carry out its declared program and its ability to stay in office, this variable is generally lower for democratic countries than for autocratic regimes.
}

sions, as in a gravity model. ${ }^{16}$ Country-pair variables are computed as ${ }^{17}$

$x_{i j, t}=x_{j, t}-x_{i, t}$

with $j=1, \ldots, 15$ the SWFs countries and $i=1, \ldots, 72$ the target countries.

We then obtain a panel dataset $(15,120$ observations) that is extremely large compared to those of other studies based on crosssectional data. ${ }^{18}$

We also consider control variables representing the SWF characteristics such as the size of the fund (LARGE), the origin of the fund (COMMODITY) and the presence of politicians on the board (POLITICIANS). LARGE is a dummy variable equal to one if the assets under management of an SWF are greater than USD 100 billion. COMMODITY is a dummy variable equal to one if the funds originate from natural resources, and POLITICIANS is a dummy variable that indicates whether politicians are present in the governance of the fund. We expect the variable $L A R G E$ to be positively related to SWF investment decisions, particularly to the decision on investment amounts. We expect COMMODITY to be positively related to SWF investment decisions abroad because countries with natural resource rent need to deal with commodity prices fluctuations and to prevent Dutch disease. More precisely, a commodity SWF that invests the proceeds from natural resources and fiscal surplus wholly abroad can mitigate the Dutch disease phenomenon and related macroeconomic consequences due to a diversification effect. ${ }^{19}$ We also expect the variable POLITICIANS to be negatively related to investment decisions: SWFs with greater political involvement tend to support domestic firms rather than investing abroad, as found by Bernstein et al. (2013). Appendix 4 reports the source and the definition of each variable employed in our study. The correlation matrix has been calculated in order to prevent multicollinearity problems. ${ }^{20}$

Table 4 reports the summary statistics concerning the variables in the model. First, we can see that the proportion of country-years with SWF investment is $2.1 \%$, which means that $97.9 \%$ of the dependent variable observations are equal to zero. The fact that the dependent variable is left-censored at zero with a great number of observations equal to zero justifies the choice of the Tobit model described above. Concerning SWFs characteristics, $96 \%$ of SWF countries have at least one SWF managed by politicians, and $86 \%$ have at least one large-sized SWF (greater than USD 100 billion). If we look at differences between target and acquiring countries' characteristics, only $9 \%$ of acquiring countries have invested in countries that speak the same language, but $17 \%$ invest in countries that share a common religion. ${ }^{21}$ Concerning the geographic distance, only $7 \%$ of the investments are made in proximal countries (at a distance of less than 1000 miles), which means that SWFs seem to be indifferent to geographical distance in their investment decision-making process. Finally, we notice that $40 \%$ of the investing countries have at least one commodity fund, stressing the importance of natural resources in the decision to establish an SWF.

\footnotetext{
16 Gravity models are often used in the international trade literature in order to analyse the determinants of bilateral trade flows. However, this type of model is not well suited for SWF investment flows, which are frequently equal to zero. 17 Country-pair variables measure the geographic, economic and institutional distance between the SWF country and the host country and have also been tested in terms of their absolute value. The results of the model with the absolute value for all these variables are unchanged. To save space, these results are not reported in the paper but are available upon request.

18 For example, in their model, Knill et al. (2012) have 3752 observations and Karolyi and Liao (2017) have 1482 observations.

19 See Corden and Neary (1982) for more details on this question.

${ }^{20}$ For the sake of space, we do not report the correlation coefficients, but these results are available upon request from the authors.

${ }^{21}$ Because only $9 \%$ of acquiring countries invest in target countries that speak the same language, we do not consider this variable in the model.
} 
Table 4

Summary statistics. This table provides the summary statistics for the variables used in our two-tiered dynamic Tobit model. Details on the variables' construction are detailed in Appendix 4.

\begin{tabular}{llllll}
\hline & Mean & Median & Min & Max & Std Dev \\
\hline SWF DUMMY & 0.021 & 0 & 0 & 1 & 0.14 \\
SWF DEAL & 1.94 & 1 & 1 & 40 & 2.74 \\
SWF AMOUNT & 499.26 & 168.25 & 0.152 & 9760 & 1003.86 \\
DIST & 6619.64 & 5414.37 & 327.46 & $17,595.10$ & 4191.05 \\
CLOSE & 0.07 & 0 & 0 & 1 & 0.26 \\
GDP & 2.69 & 2.70 & -12.82 & 24.16 & 5.48 \\
INFLATION & -0.007 & -0.19 & -25.40 & 12.24 & 4.98 \\
REER & 4.82 & 1.06 & -31.81 & 217.28 & 17.66 \\
POLITY & -0.54 & -0.6 & -1 & 0.8 & 0.39 \\
KAOPEN & 0.12 & 0 & -0.84 & 1 & 0.46 \\
RELIGION & 0.17 & 0 & 0 & 1 & 0.38 \\
LANGUAGE & 0.09 & 0 & 0 & 1 & 0.28 \\
GOVSTAB & 1.98 & 2.13 & -4.46 & 5.92 & 1.87 \\
CORRUPTION & -0.23 & -0.10 & -3.5 & 3.5 & 1.64 \\
COMMODITY & 0.42 & 0 & 0 & 1 & 0.49 \\
LARGE & 0.86 & 1 & 0 & 1 & 0.35 \\
POLITICIANS & 0.96 & 1 & 0 & 1 & 0.21 \\
\hline
\end{tabular}

5.2. Results

\subsubsection{One-tiered versus two-tiered dynamic Tobit panel models}

We test the observation that target country factors do not have the same impacts on the investment decision and the amount to be invested, as indicated in H2. For that, we have estimated both models for comparison: the one-tiered dynamic Tobit model for panel data and indi- vidual random effects developed by Chang (2011a) described above in Eqs. (1) and (2) and the two-tiered dynamic panel Tobit model initiated by Chang (2011a,b), and completed by Xun and Lubrano (2016) described in Eqs. (4) and (5). The results of the one-tiered and twotiered dynamic panel Tobit models with individual random effects are reported in Table 5.

Table 5

One-tiered and two-tiered dynamic Tobit panel results. This table reports results for the one-tiered and two-tiered dynamic panel Tobit models. Column (2) gives the results of the one-tiered model, columns (3) and (4) report the results for the first equation (decision to invest) and the second equation (amount to be invested) of the two-tiered model, respectively. The summary statistics of these variables are presented in Table 4. Appendix 4 presents details on the variable construction.

\begin{tabular}{|c|c|c|c|}
\hline & \multirow[t]{2}{*}{ One-tier } & \multicolumn{2}{|l|}{ Two-tier } \\
\hline & & Eq. (1) & Eq. (2) \\
\hline CONSTANT & $\begin{array}{l}-112.600^{* * *} \\
{[20.330]}\end{array}$ & $\begin{array}{l}-5.6680 \text { *** } \\
{[0.4553]}\end{array}$ & $\begin{array}{l}14.749^{* * *} \\
{[0.711]}\end{array}$ \\
\hline INFLATION & $\begin{array}{l}1.0870 * * \\
{[0.3593]}\end{array}$ & $\begin{array}{l}0.0023 \\
{[0.0079]}\end{array}$ & $\begin{array}{l}-0.0013 \\
{[0.0237]}\end{array}$ \\
\hline REER & $\begin{array}{l}-0.1304 \\
{[0.0705]}\end{array}$ & $\begin{array}{l}0.0026 \\
{[0.0019]}\end{array}$ & $\begin{array}{l}0.0166 * * \\
{[0.0063]}\end{array}$ \\
\hline POLITY & $\begin{array}{l}-11.6000 \\
{[6.349]}\end{array}$ & $\begin{array}{l}-0.8367^{* * *} \\
{[0.2465]}\end{array}$ & $\begin{array}{l}-1.6312^{* * *} \\
{[0.4714]}\end{array}$ \\
\hline KAOPEN & $\begin{array}{l}14.8500 * \\
{[7.252]}\end{array}$ & $\begin{array}{l}0.3040 \\
{[0.1879]}\end{array}$ & $\begin{array}{l}-0.9840^{* * *} \\
{[0.3402]}\end{array}$ \\
\hline GOVSTAB & $\begin{array}{l}1.6390 \\
{[0.8935]}\end{array}$ & $\begin{array}{l}1.1410^{* * *} \\
{[0.0353]}\end{array}$ & $\begin{array}{l}0.0520 \\
{[0.0740]}\end{array}$ \\
\hline POLITICIANS & $\begin{array}{l}15.1500 * \\
{[7.0250]}\end{array}$ & $\begin{array}{l}0.3371 * \\
{[0.1436]}\end{array}$ & $\begin{array}{l}-0.0768 \\
{[0.2713]}\end{array}$ \\
\hline DIST & $\begin{array}{l}-0.0011 * \\
{[0.0005]}\end{array}$ & $\begin{array}{l}-0.0001 \\
{[0.0001]}\end{array}$ & $\begin{array}{l}-0.0001 \\
{[0.0001]}\end{array}$ \\
\hline GDP & $\begin{array}{l}0.0230 \\
{[0.2170]}\end{array}$ & $\begin{array}{l}-0.0001 \\
{[0.0065]}\end{array}$ & $\begin{array}{l}-0.0089 \\
{[0.0211]}\end{array}$ \\
\hline CORRUPTION & $\begin{array}{l}-1.7880 \\
{[1.6400]}\end{array}$ & $\begin{array}{l}0.0066 \\
{[0.0536]}\end{array}$ & $\begin{array}{l}-0.0060 \\
{[0.1069]}\end{array}$ \\
\hline RELIGION & $\begin{array}{l}-1.0280 \\
{[1.3340]}\end{array}$ & $\begin{array}{l}-0.2148 \\
{[0.2004]}\end{array}$ & $\begin{array}{l}-0.1517 \\
{[0.3693]}\end{array}$ \\
\hline LARGE & $\begin{array}{l}30.0000^{* * *} \\
{[8.0330]}\end{array}$ & $\begin{array}{l}0.0491 \\
{[0.1044]}\end{array}$ & $\begin{array}{l}-0.2088 \\
{[0.1987]}\end{array}$ \\
\hline COMMODITY & $\begin{array}{l}-28.130 * * \\
{[9.1100]}\end{array}$ & $\begin{array}{l}-0.1817 \\
{[0.1193]}\end{array}$ & $\begin{array}{l}-0.1479 \\
{[0.2238]}\end{array}$ \\
\hline$\lambda_{1}$ & $\begin{array}{l}-37.9600 \\
{[34.5900]}\end{array}$ & $\begin{array}{l}0.1108^{* * *} \\
{[0.0150]}\end{array}$ & $\begin{array}{l}0.0843 * * \\
{[0.0263]}\end{array}$ \\
\hline$\lambda_{2}$ & $\begin{array}{l}7.3310 \\
{[5.8070]}\end{array}$ & $\begin{array}{l}0.3811 \\
{[0.2416]}\end{array}$ & $\begin{array}{l}1.4477 * * \\
{[0.4956]}\end{array}$ \\
\hline $\begin{array}{l}\text { Log-likelihood } \\
\text { BIC }\end{array}$ & $\begin{array}{l}-2331.121 \\
4835.47\end{array}$ & $\begin{array}{l}-1790.16 \\
3897.905\end{array}$ & \\
\hline
\end{tabular}

${ }^{*}$ Significant at $5 \% ;{ }^{* *}$ significant at $1 \% ;{ }^{* *}$ significant at $0.1 \%$. Standard errors are in brackets. 
Several elements illustrate the performance of the two-tiered dynamic Tobit panel model compared to the one-tiered model. First, the log-likelihood function has a much higher value than that of the corresponding one-tiered model and the BIC value is smaller in the two-tiered. ${ }^{22}$ Second, this model relaxes many constraints that allow the asymmetric effects between the two equations to be captured. In particular, variables capturing the political distance between both countries, such as POLITY, GOV STAB and the variable measuring the country's degree of capital account (KAOPEN), are significant in the twotiered model but not in the one-tiered model. Finally, the individual effect parameters $\left(\lambda^{\prime} s\right)$ are significant in the two-tiered model but not in the one-tiered model, which means that the dynamic component of the model is significantly different from zero only when we consider the two-tiered model. This finding suggests that ignoring the two-stage nature of the investment decision and assuming that the country factors have the same impact in both stages as in a one-tiered Tobit model is therefore a restrictive approach and leads to biased conclusions, which confirms H2. Our result also confirms the significance of the lagged dependent variable in the two-tiered panel model compared to the onetiered panel model, meaning that the dynamic component is crucial in the SWF's investment decision process and should be taken into account in the two-tiered model.

\subsubsection{Results of the two-tiered dynamic Tobit panel model}

Results of the two-tiered dynamic Tobit model with panel data are given in Table 6. Panel A displays the results of the first stage (investment decision), and Panel B shows the results of the second stage (the decision about the amount to invest). The same explanatory variables have been included in each step of the two-tiered model. For both equations, we include in the first column all the possible explanatory variables, corresponding to the full model. We then report the estimates of different restricted versions of this model with variables estimated one by one (columns (2) to (6)). Column (7) gives the results of the most parsimonious model.

First, we find that most country-pair variables are significant in both Panel A and in Panel B, which means that country factors (macroeconomic, geographical, institutional and cultural factors) turn out to be key determinants of SWFs' investments. This result is also in line with the conclusions of some recent studies, according to which SWFs' motivations may be non-financial (Chhaochharia and Laeven (2009), Bernstein et al. (2013) or Knill et al. (2012)). The importance of country factors also constitutes a key point in order to evaluate the role of SWF investments in crisis periods. If they were exclusively driven by the quest for financial returns, they could be a destabilizing force for financial markets. In contrast, we show that macroeconomic determinants are crucial for SWFs. This finding tends to support the idea that SWF investments follow long-run horizon strategies, constituting potential market stabilizers in periods of turmoil.

Second, our estimation results indicate the following. i) Countrylevel factors have a positive impact not only on the investment decision but also on the choice of the amount to be invested, which is conditional on the investment decision. This situation is clearly the case for the variable POLITY, which is significant in both equations. ii) These country factors driving the SWF investment decision are not the same as those used to set the amount to be invested, consistent with H2. More precisely, we find that the financial openness index KAOPEN does not matter for the decision to invest, whereas a high difference in the financial openness index between the SWF and target country tends to decrease the average value of the deal. In contrast, a higher government stability

\footnotetext{
${ }^{22}$ In the one-tiered model, we have 15 parameters for $\beta$ and $\lambda$ and three other parameters in the error component (totally 18 parameters), while in the twotiered model, we have double the number of parameters for $\beta$ and $\lambda$, but the two tiers share the same set of error components as in the one-tiered model (a total of 33 parameters).
}

difference (GOVSTAB) increases the probability of an SWF investment but does not affect the amount to be invested. In support of this result, Knill et al. (2012)) find that bilateral political relations between SWF and target countries are an important determinant of why SWFs invest in a given country, but they matter less in determining how much to invest. In light of our results, we can conclude that SWFs' investment decisions are the outcome of a complex process. It is therefore essential to distinguish the factors that influence the decision to invest from those that determine the amount of the investment.

Regarding H1, which stresses that SWFs tend to invest in countries that share similar macroeconomic, geographical and institutional characteristics, we find some contrasting results on macroeconomic and cultural factors. While the variable GDP is never significant, we observe that the coefficient for REER is significantly positive in Panel B but not in Panel A, whereas it is the reverse for the variable INFLATION. This finding suggests that as the difference in terms of REER increases, the tendency for an SWF to invest large amounts increases. In contrast, as the difference in terms of inflation increases, an SWF becomes more likely to invest. These results can be interpreted to mean that SWFs may prefer to invest in countries that do not share the same macroeconomic characteristics as the home country. As seen in the previous section, the majority of the most active SWFs are located in Asia and the Middle East and show a clear preference to invest in developed countries (North America and West Europe) that have a more stable economy in terms of both inflation and exchange rates.

Concerning cultural factors, unlike Chhaochharia and Laeven (2009) and Bernstein et al. (2013), we do not find empirical support that SWFs are focused on countries that share a similar culture or are geographically close (the variables RELIGION and DIST are not significant in Panel A or in Panel B). This result does not corroborate the idea that SWFs invest while keeping in mind religious or cultural proselytism (Islamic finance). In the same way, we do not find evidence of a home or a region bias in SWFs' investment policies.

However, H1 is well supported by our results on political and institutional factors. The significance of POLITY, GOV STAB, KAOPEN and POLITICIANS clearly reveal that country factors are essential to SWFs' investment decision process. More specifically, we find that POLITY and KAOPEN are negatively related to SWF investments (the investment decision and/or the amount to be invested), meaning that SWFs are more likely to invest in countries with which they have lesser differences in their levels of democracy and financial openness. The first result, which is consistent with Karolyi and Liao (2017), means that SWFs prefer to invest in countries that have a similar level of democracy as the home country. ${ }^{23}$ Moreover, the variable GOV STAB is positively related to SWFs' investment decisions but does not impact the amounts to be invested, which means that an SWF is more likely to invest in a country when government stability is different. Contrary to Bernstein et al. (2013), we find that the presence of politicians in the fund significantly influences the decision to invest abroad. Finally, the characteristics of the fund itself, such as its size or its origin (whether a commodity fund or not), do not seem to influence its investment strategy.

H3 deals with the autoregressive terms and assumes that when an SWF invests in a country, it is likely to invest in that country again in the future. In other words, the true state dependence coefficients $\left(\lambda^{\prime} s\right)$ would be significantly different from 0 . It appears that indeed, in Panel A, only $\lambda_{1}$ is significant, which indicates that an SWF thus tends to reinvest in a country in which it has already invested. We also observe that $\lambda_{2}$ is not significantly different from 0 , which indicates that there is no investment barrier for countries in which SWFs have never invested. For Panel B, both $\lambda_{1}$ and $\lambda_{2}$ are significant, supporting the idea of inertia in the amount invested by SWFs.

\footnotetext{
${ }^{23}$ However, Knill et al. (2012)) find that POLITY is positively related to SWF investment (the investment decision and the amount to be invested).
} 
Table 6

Two-Tiered Dynamic Tobit Panel Results. This table reports results for the panel analysis of investment decisions (Panel A: first equation of the two-tiered Tobit model) and the average amount invested by SWFs (Panel B: second equation of the two-tiered Tobit. Column (1) gives the results for the full model, columns (2) to (6) report the estimates of different restricted versions of this model with variables estimated one by one. Column (7) gives the results of the parsimonious model. The summary statistics of these variables are presented in Table 4. Appendix 4 presents details on the variables' construction.

\begin{tabular}{|c|c|c|c|c|c|c|c|}
\hline & (1) & (2) & (3) & (4) & (5) & (6) & (7) \\
\hline \multicolumn{8}{|c|}{ Panel A: decision to invest (first equation) } \\
\hline \multirow[t]{2}{*}{ CONSTANT } & $-5.668^{* * *}$ & $-5.335 * * *$ & $-5.401 * * *$ & $-5.807 * * *$ & $-5.892 * * *$ & $-5.862 * * *$ & $-5.797 * * *$ \\
\hline & {$[0.455]$} & {$[0.3772]$} & {$[0.355]$} & [0.334] & {$[0.408]$} & [0.433] & {$[0.459]$} \\
\hline \multirow[t]{2}{*}{ INFLATION } & 0.002 & $0.024 * *$ & & & & & 0.025 \\
\hline & [0.008] & {$[0,008]$} & & & & & [0.112] \\
\hline \multirow[t]{2}{*}{ REER } & 0.003 & & 0.002 & & & & 0.002 \\
\hline & {$[0.002]$} & & {$[0.002]$} & & & & [0.003] \\
\hline \multirow[t]{2}{*}{ POLITY } & $-0.837^{* * *}$ & & & $-1.136^{* * *}$ & & & $-0.816 * *$ \\
\hline & {$[0.247]$} & & & [0.174] & & & {$[0.257]$} \\
\hline \multirow[t]{2}{*}{ KAOPEN } & 0.304 & & & & -0.040 & & 0.245 \\
\hline & {$[0.188]$} & & & & {$[0.181]$} & & [0.157] \\
\hline \multirow[t]{2}{*}{ GOV STAB } & $0.141^{* * *}$ & & & & & $0.208 * * *$ & $0.128 * * *$ \\
\hline & {$[0.035]$} & & & & & {$[0.033]$} & [0.037] \\
\hline \multirow[t]{2}{*}{ POLITICIANS } & $0.337 *$ & & & & & & 0.232 \\
\hline & [0.144] & & & & & & [0.138] \\
\hline \multirow[t]{2}{*}{ DIST } & -0.000 & & & & & & \\
\hline & {$[0.000]$} & & & & & & \\
\hline GDP & -0.000 & & & & & & \\
\hline & {$[0.007]$} & & & & & & \\
\hline CORRUPTION & 0.007 & & & & & & \\
\hline & [0.054] & & & & & & \\
\hline RELIGION & -0.215 & & & & & & \\
\hline & {$[0.200]$} & & & & & & \\
\hline LARGE & 0.049 & & & & & & \\
\hline & [0.104] & & & & & & \\
\hline COMMODITY & -0.182 & & & & & & \\
\hline & [0.119] & & & & & & \\
\hline$\lambda_{1}$ & $0.111^{* * *}$ & $0.132 * * *$ & $0.137 * * *$ & $0.133^{* * *}$ & $0.394 * * *$ & $0.382^{* * *}$ & $0.114^{* * *}$ \\
\hline & {$[0.015]$} & {$[0.016]$} & {$[0.015]$} & [0.015] & {$[0.062]$} & [0.049] & {$[0.021]$} \\
\hline$\lambda_{2}$ & 0.381 & $0.480 *$ & $0.545 *$ & $0.524 *$ & 0.420 & 0.193 & 0.440 \\
\hline & {$[0.242]$} & {$[0,235]$} & [0.233] & {$[0.233]$} & [0.284] & {$[0.212]$} & [0.332] \\
\hline Panel B: Amoun & to be investe & econd equatic & & & & & \\
\hline CONSTANT & $14.749^{* * *}$ & $14.44^{* * *}$ & $14.327^{* * *}$ & $13.514^{* * *}$ & -0.200 & -0.598 & $14.260 * * *$ \\
\hline & [0.711] & [0.529] & [0.521] & [0.483] & [0.288] & [0.568] & {$[0.684]$} \\
\hline INFLATION & -0.001 & $0.046 *$ & & & & & 0.011 \\
\hline & {$[0.024]$} & {$[0.021]$} & & & & & [0.019] \\
\hline REER & $0.017 * *$ & & $0.018 * *$ & & & & $0.015 *$ \\
\hline & {$[0.006]$} & & {$[0.061]$} & & & & {$[0.007]$} \\
\hline POLITY & $-1.631^{* * *}$ & & & $-2.022 * * *$ & & & $-1.566^{* * *}$ \\
\hline & {$[0.471]$} & & & [0.293] & & & {$[0.397]$} \\
\hline KAOPEN & $-0.984 * *$ & & & & $-1.582^{* * *}$ & & $-1.081^{* * *}$ \\
\hline & {$[0.340]$} & & & & {$[0.320]$} & & {$[0.319]$} \\
\hline GOV STAB & 0.052 & & & & & $0.180 * *$ & 0.041 \\
\hline & [0.074] & & & & & {$[0.055]$} & {$[0.068]$} \\
\hline POLITICIANS & -0.077 & & & & & & 0.0212 \\
\hline & {$[0.271]$} & & & & & & {$[0.260]$} \\
\hline DIST & -0.000 & & & & & & \\
\hline & {$[0.000]$} & & & & & & \\
\hline GDP & -0.009 & & & & & & \\
\hline & [0.021] & & & & & & \\
\hline CORRUPTION & -0.006 & & & & & & \\
\hline & [0.107] & & & & & & \\
\hline RELIGION & -0.151 & & & & & & \\
\hline & [0.369] & & & & & & \\
\hline LARGE & -0.209 & & & & & & \\
\hline & [0.199] & & & & & & \\
\hline COMMODITY & -0.148 & & & & & & \\
\hline & {$[0.224]$} & & & & & & \\
\hline$\lambda_{1}$ & $0.084 * *$ & $0.114^{* * *}$ & 0.118 & $0.110^{* * *}$ & $0.454 * * *$ & $0.490 * * *$ & $0.084 *$ \\
\hline & {$[0.026]$} & {$[0.025]$} & {$[0.024]$} & {$[0.024]$} & {$[0.053]$} & {$[0.076]$} & [0.038] \\
\hline$\lambda_{2}$ & $1.448 * *$ & $2.014^{* * *}$ & $2.051^{* * *}$ & $1.912^{* * *}$ & $1.983^{* * *}$ & $2.238 * * *$ & $1.446 *$ \\
\hline & {$[0.496]$} & {$[0.455]$} & {$[0.446]$} & {$[0.441]$} & {$[0.313]$} & {$[0.414]$} & [0.639] \\
\hline$\sigma_{u}$ & $1.503 * * *$ & $1.584^{* * *}$ & $1.568 * * *$ & $1.548 * * *$ & $1.511 * * *$ & $1.565 * * *$ & $1.486 * * *$ \\
\hline & {$[0.056]$} & {$[0.064]$} & {$[0.056]$} & {$[0.068]$} & {$[0.052]$} & {$[0.067]$} & {$[0.052]$} \\
\hline$\sigma_{d}$ & $1.598^{* * *}$ & $1.632^{* * *}$ & $1.624^{* * *}$ & $1.619^{* * *}$ & $2.138^{* * *}$ & $1.967^{* * *}$ & $1.578^{* * *}$ \\
\hline & [0.161] & [0.173] & [0.169] & {$[0.100]$} & [0.127] & [0.219] & {$[0.161]$} \\
\hline$\zeta$ & $-0.321 * * *$ & $-0.339 * * *$ & $-0.274 * * *$ & $-0.310^{* * *}$ & $-0.360^{* * *}$ & $-0.376^{* * *}$ & $-0.319^{* * *}$ \\
\hline & [0.054] & [0.056] & [0.053] & [0.056] & {$[0.041]$} & {$[0.046]$} & {$[0.050]$} \\
\hline Log-Likelihood & -1790.16 & -2040.09 & -2042.39 & -2012.29 & -1990.08 & -1975.75 & -1911.33 \\
\hline $\mathrm{BIC}$ & 3897.905 & 4186.042 & 4190.642 & 4130.442 & 4086.022 & 4057.362 & 4024.759 \\
\hline Iterations & 697 & 472 & 522 & 476 & 388 & 406 & 532 \\
\hline
\end{tabular}

\footnotetext{
* Significant at 5\%; ${ }^{* *}$ significant at $1 \%$; *** significant at $0.1 \%$. Standard errors are in brackets.
} 
Table 7

Two-tiered dynamic Tobit panel results - Robustness checks. This table reports results for the panel analysis of the decision to invest and the average amount invested by SWFs, taking into account the sign of the difference. The explanatory variables $(x)$ have been calculated with the following formula: $x_{i j}=x_{j}-x_{i}$, where $i$ is the target country and $j$ is the acquirer country. We then decided to reestimate the model by taking into account both the cases in which $x_{j}>x_{i}(x i j+)$ and $x_{j}<x_{i}$ (xij-). Column (1) gives the results for Panel A (decision to invest), and column (2) gives the results for Panel B (amounts to be invested).

\begin{tabular}{|c|c|c|}
\hline & Panel A & Panel B \\
\hline CONSTANT & $\begin{array}{l}-4.757^{* * *} \\
{[0.421]}\end{array}$ & $\begin{array}{l}14.440^{* * *} \\
{[0.529]}\end{array}$ \\
\hline INFLATION+ & $\begin{array}{l}0.026 \\
{[0.019]}\end{array}$ & $\begin{array}{l}-0.025 \\
{[0.035]}\end{array}$ \\
\hline INFLATION- & $\begin{array}{l}0.050 * * \\
{[0.018]}\end{array}$ & $\begin{array}{l}0.019 \\
{[0.038]}\end{array}$ \\
\hline REER+ & $\begin{array}{l}0.012 \\
{[0.008]}\end{array}$ & $\begin{array}{l}0.033 \\
{[0.023]}\end{array}$ \\
\hline REER- & $\begin{array}{l}-0.005 \\
{[0.004]}\end{array}$ & $\begin{array}{l}-0.002 \\
{[0.009]}\end{array}$ \\
\hline POLITY+ & $\begin{array}{l}-0.758 \\
{[0.600]}\end{array}$ & $\begin{array}{l}-1.503 \\
{[1.160]}\end{array}$ \\
\hline POLITY- & $\begin{array}{l}-0.344 \\
{[0.375]}\end{array}$ & $\begin{array}{l}-1.361 * * \\
{[0.473]}\end{array}$ \\
\hline KAOPEN+ & $\begin{array}{l}-0.026 \\
{[0.339]}\end{array}$ & $\begin{array}{l}-1.637^{* * *} \\
{[0.453]}\end{array}$ \\
\hline KAOPEN- & $\begin{array}{l}1.091^{* * * *} \\
{[0.307]}\end{array}$ & $\begin{array}{l}0.116 \\
{[0.509]}\end{array}$ \\
\hline GOV STAB+ & $\begin{array}{l}0.177^{* * * *} \\
{[0.039]}\end{array}$ & $\begin{array}{l}0.080 \\
{[0.074]}\end{array}$ \\
\hline GOV STAB- & $\begin{array}{l}0.052 \\
{[0.097]}\end{array}$ & $\begin{array}{l}-0.337 \\
{[0.201]}\end{array}$ \\
\hline$\lambda_{1}$ & $\begin{array}{l}0.084 * * \\
{[0.074]}\end{array}$ & $\begin{array}{l}0.081 * * \\
{[0.025]}\end{array}$ \\
\hline$\lambda_{2}$ & $\begin{array}{l}0.208 * * * \\
{[0.235]}\end{array}$ & $\begin{array}{l}1.433 * * \\
{[0.447]}\end{array}$ \\
\hline $\begin{array}{l}\sigma_{u} \\
\sigma_{d} \\
\eta\end{array}$ & $\begin{array}{l}1.470^{* * *}[0.049] \\
1.498^{* * *}[0.127] \\
-0.191 * * *[0.056]\end{array}$ & \\
\hline $\begin{array}{l}\text { Log-Likelihood } \\
\text { Iterations }\end{array}$ & $\begin{array}{l}-1833.78 \\
538\end{array}$ & \\
\hline
\end{tabular}

Finally, our error component assumption with consideration of a random effect $+\mathrm{AR}(1)$ process allows us to capture the spurious state dependence parameter $\zeta$ (auto-correlation of errors) in a very consistent and significant way across different specifications. Thus, we managed to avoid the unexpected estimation confusion in identifying the true state dependence features.

\subsection{Refinement of country-pair variables}

The results found in Table 5 allow us to determine if country-pair variables are significant but not to determine the sense of the difference: does the probability of investment made by the SWF country (the investment decision and/or the amount to be invested) tend to increase or decrease when the difference between SWF country factors and those of target country is negative (positive)? To answer this question, the country-pair variables described in Eq. (7) were split, allowing us to determine if there is a difference in favor of the acquirer or of the host country:

$x_{i j, t,+}=x_{j, t}-x_{i, t} \quad$ with $x_{j}>x_{i}$

$x_{i j, t,-}=x_{j, t}-x_{i, t} \quad$ with $x_{j}<x_{i}$

The results are displayed in Table 7. Panel A displays the results of the first stage (investment decision) and Panel B the results of the second stage (the decision about the amount to invest). These new results confirm the role of political and institutional variables in the attraction of SWFs: stability of the government, democracy index and degree of capital account openness. In particular, we find that political stability of the target country is a factor that contributing to the attractiveness when acquirer country is less stable politically (GOV STAB + is positive and highly significant in Panel A).

Once again, we find that the determinants driving the SWF investment decision are not the same as those used to set the amount to be invested. More precisely, POLITY- and KAOPEN+ are negative and significant in panel $\mathrm{B}$, which means that SWFs are more prone to investing large amounts in countries that are less democratic and more financially open. Strikingly, KAOPEN- is significantly positive in panel A, whereas KAOPEN+ is significantly negative in panel $\mathrm{B}$. This result means that the target country's degree of financial openness matters for both the SWFs' investment decision and the amount to be invested.

\section{Conclusion}

One of the main concerns about SWFs' investment strategy, which has been widely studied in the literature, is that SWFs could invest for non-financial reasons. This paper aims to shed light on the question of the motivation of SWFs in their investment decision and, more precisely, whether country-level factors such as macroeconomic, political, institutional or cultural factors can explain this decision. More specifically, we develop an approach that takes into account the fact that the cross-border investment decision for an SWF is the outcome of a complex decision-making process. To do so, we estimate a two-tiered dynamic Tobit panel model recently developed by Chang (2011b) and extended by Xun and Lubrano (2016), which allows us to test three important aspects of this decision-making process: i) the independence 
of the SWF decision regarding where and how much to invest (which justifies the choice of the two-tiered model); ii) the persistence phenomenon in the investment decision, which is accounted for in the dynamic dimension of the model; iii) the inclusion of the temporal dimension and the unobserved heterogeneity in the dependent variable considered in the panel dimension of the model.

Several insights emerge from our analysis. From an econometric perspective, the key insight from this paper is that the choice of the model allows us to independently estimate the decision of where and how much to invest. The results of the analysis indicate that the determinants driving the SWF investment decision are not the same as those used to fix the amount to be invested. This finding suggests that ignoring the two-stage nature of the investment decision and assuming that the country factors have the same impact in both stages as in a Tobit model is a restrictive approach. On the basis of our results, we can conclude that country-level factors are key determinants not only of the investment decision but also of the choice of the amount to be invested. In the same spirit, we find that the dynamic component of the twotiered panel model is crucial, suggesting that SWFs have a tendency to invest in the target country in the years after the decision to invest has been taken and to do so in a persistent, dynamic manner in terms of the amounts invested.

The results of the model also suggest that country-level factors can affect SWFs' investment decision, which means that financial motives are not the exclusive target of their investment strategy. In particular, we find that SWF investments are driven by macroeconomic, political and institutional considerations. The findings regarding macroeconomic variables show that more mature economies tend to attract SWF investments. Our findings also show that SWFs that involve politicians have a much greater likelihood of investing abroad and tend to be attracted to countries with greater political stability. Finally, we find that SWFs are more prone to investing large amounts in countries that are less democratic and more financially open, which means that the determinants driving the investment decision are not the same as those used to set the amount to be invested. Taken as a whole, our results lend support to the idea that SWFs are safe in the choice of target countries concerning their investment decisions but behave as more opportunistic investors concerning the amount to be invested. Our results shed new light on SWFs' investment strategy for regulators seeking to enhance financial stability, thereby motivating - in line with the Santiago principles - a better evaluation of macroeconomic risks.

\section{Appendices}

Appendix 1. Characteristics of SWFs

\begin{tabular}{|c|c|c|c|c|c|c|}
\hline Country & Fund name & $\begin{array}{l}\text { Assets Under } \\
\text { Management }\end{array}$ & $\begin{array}{l}\text { Founding } \\
\text { date }\end{array}$ & $\begin{array}{l}\text { Source of the } \\
\text { funds }\end{array}$ & Policy purpose & $\begin{array}{l}\text { Presence of politician } \\
\text { on the SWF board }\end{array}$ \\
\hline Australia & Queensland Investment Corporation & 70.6 & 1992 & Fiscal & Unknown & Yes \\
\hline Australia & $\begin{array}{l}\text { Victorian Funds Management Corpo- } \\
\text { ration }\end{array}$ & 46.6 & 1994 & Unknown & Unknown & No \\
\hline Australia & Australian Future Fund & 95 & 2006 & Non-commodity & Saving & No \\
\hline Bahrain & $\begin{array}{l}\text { Bahrain Mumtalakat Holding Com- } \\
\text { pany }\end{array}$ & 10.5 & 2006 & Non-commodity & Saving Reserve investment & Unknown \\
\hline China & China Investment Corporation & 652.7 & 2007 & Non-commodity & Reserve investment & Yes \\
\hline China & China SAFE Investment & 567.9 & 1997 & Non-commodity & Reserve investment & Yes \\
\hline China & National Social Security Fund & 201.6 & 2000 & Non-commodity & Reserve investment & Yes \\
\hline China & China-Africa Development Fund & 5 & 2007 & Non-commodity & Reserve investment & Yes \\
\hline France & France Strategic investment fund & 25.5 & 2008 & Non-commodity & Pension reserve & Yes \\
\hline Kazakhstan & Samruk Kazyna National Wealth Fund & 77.5 & 2008 & Non-commodity & $\begin{array}{l}\text { Stabilization Saving Pension } \\
\text { reserve }\end{array}$ & No \\
\hline Kuwait & Kuwait Investment Authority & 548 & 1953 & Oil and gas & Stabilization Saving & Yes \\
\hline Libya & Libyan Investment Authority & 66 & 2006 & Oil and gas & Saving & Yes \\
\hline Malaysia & Khazanah Nasional & 40.5 & 1993 & Non-commodity & Saving & No \\
\hline $\begin{array}{l}\text { New } \\
\text { Zealand }\end{array}$ & New Zealand Superannuation Fund & 28.98 & 2001 & Non-commodity & Pension reserve & Yes \\
\hline Oman & State General Reserve Fund & 13 & 1980 & Oil and gas & $\begin{array}{l}\text { Stabilization Reserve invest- } \\
\text { ment }\end{array}$ & No \\
\hline Oman & Oman Investment Fund & 6 & 2006 & Oil and gas & Reserve investment & No \\
\hline Qatar & Qatar Investment Authority & 170 & 2005 & Oil and gas & Saving Reserve investment & No \\
\hline $\begin{array}{l}\text { Saudi Ara- } \\
\text { bia }\end{array}$ & Kingdom Holding & 19.6 & 1996 & Oil and gas & Reserve investment & Unknown \\
\hline Singapore & $\begin{array}{l}\text { Government of Singapore Investment } \\
\text { Corporation }\end{array}$ & 320 & 1981 & Non-commodity & Saving Reserve investment & No \\
\hline Singapore & Temasek & 177 & 1974 & Non-commodity & Saving Reserve investment & No \\
\hline South Korea & Korea Investment Corporation & 72 & 2005 & Non-commodity & Reserve investment & Yes \\
\hline UAE & Dubai Holding & NA & 2004 & Oil and gas & Unknown & Yes \\
\hline UAE & Dubai World & NA & 2004 & Oil and gas & Reserve investment & Yes \\
\hline UAE & $\begin{array}{l}\text { Abu Dhabi Mubadala Development } \\
\text { Company }\end{array}$ & 60.9 & 2002 & Oil and gas & Reserve investment & No \\
\hline UAE & $\begin{array}{l}\text { Abu Dhabi International Petroleum } \\
\text { Investment Company }\end{array}$ & 68.4 & 1984 & Oil and gas & Reserve investment & Yes \\
\hline UAE & Abu Dhabi Investment Authority & 773 & 1976 & Oil and gas & Saving Reserve investment & Yes \\
\hline UAE & Ras-al-Khaimah Investment Authority & 1.2 & 2005 & Oil and gas & Reserve investment & No \\
\hline UAE & Investment Corporation of Dubai & 70 & 2006 & Oil and gas & Reserve investment & No \\
\hline UAE & Abu Dhabi Investment Council & 90 & 2007 & Oil and gas & Reserve investment & Yes \\
\hline
\end{tabular}


Appendix 2. Literature review: Country-level factors as drivers of SWF investments

\begin{tabular}{|c|c|c|c|c|c|c|}
\hline Title & Authors & Year & Model & Endogenous variable & Explanatory variables & Main Results \\
\hline $\begin{array}{l}\text { The investment strategies of } \\
\text { SWFs }\end{array}$ & $\begin{array}{l}\text { Bernstein, } \\
\text { Lerner and } \\
\text { Scholar }\end{array}$ & 2013 & $\begin{array}{l}\text { Cross-section } \\
\text { OLS Regression }\end{array}$ & Acquisition stake & Political factors & $\begin{array}{l}\text { The involvement of external managers and the } \\
\text { presence of politicians on the board lead to } \\
\text { smaller acquisitions, but the impact of politi- } \\
\text { cians is weaker than that of external managers. }\end{array}$ \\
\hline $\begin{array}{l}\text { SWF: their investment strate- } \\
\text { gies and performance }\end{array}$ & $\begin{array}{l}\text { Chhaochharia } \\
\text { and Laeven }\end{array}$ & 2009 & $\begin{array}{l}\text { Cross-sectional } \\
\text { gravity model }\end{array}$ & $\begin{array}{l}\text { log difference between the share } \\
\text { of country j in total equity invest- } \\
\text { ment by SWFs from country } \mathrm{i} \\
\text { and the share of country } \mathrm{j} \text { in the } \\
\text { world equity market }\end{array}$ & $\begin{array}{l}\text { Financial, geographi- } \\
\text { cal, cultural factors }\end{array}$ & $\begin{array}{l}\text { SWFs tend to invest in countries that share a } \\
\text { common culture, but this cultural bias disap- } \\
\text { pears with repeated investments. SWFs display } \\
\text { industry bias (more investments in oil com- } \\
\text { pany stocks) and tend to invest mostly in large- } \\
\text { capitalization stocks. }\end{array}$ \\
\hline $\begin{array}{l}\text { What is different about } \\
\text { government-controlled } \\
\text { acquirers in cross-border } \\
\text { acquisitions }\end{array}$ & $\begin{array}{l}\text { Karolyi and } \\
\text { Liao }\end{array}$ & 2017 & $\begin{array}{l}\text { Cross-sectional } \\
\text { logit model }\end{array}$ & $\begin{array}{l}\text { Dummy variable equal to } 1 \text { if } \\
\text { the firm is targeted by SWFs } \\
\text { and } 0 \text { if it is targeted by other } \\
\text { government-controlled entities }\end{array}$ & Financial factors & $\begin{array}{l}\text { SWFs are more likely to be influenced by mar- } \\
\text { ket valuations relative to other government- } \\
\text { led acquirers. There are important differences } \\
\text { between government-led acquirers and SWFs. } \\
\text { SWF-led acquisitions are less likely to fail and } \\
\text { are more likely to pursue acquirers that have } \\
\text { more total assets and fewer financial con- } \\
\text { straints. }\end{array}$ \\
\hline $\begin{array}{l}\text { Bilateral Political Relations } \\
\text { and SWF investment }\end{array}$ & $\begin{array}{l}\text { Knill, Lee } \\
\text { and Mauck }\end{array}$ & 2012 & $\begin{array}{l}\text { Cross-section } \\
\text { Tobit and Cragg } \\
\text { Models }\end{array}$ & Investment amount & $\begin{array}{l}\text { Economic, Financial, } \\
\text { Institutional, politi- } \\
\text { cal and geographical } \\
\text { factors }\end{array}$ & $\begin{array}{l}\text { Economic factors are negatively related to the } \\
\text { investment decision of SWFs, whereas geo- } \\
\text { graphical and institutional distances are posi- } \\
\text { tively related to the decision to invest. Politi- } \\
\text { cal relations are an important factor in deter- } \\
\text { mining where SWFs invest but matter less in } \\
\text { determining the size of the investment. }\end{array}$ \\
\hline $\begin{array}{l}\text { SWF Investments: from } \\
\text { firm-level preferences to } \\
\text { natural endowments }\end{array}$ & Avendano & 2012 & $\begin{array}{l}\text { Cross-sectional } \\
\text { regression and } \\
\text { gravity model }\end{array}$ & Bilateral holding & $\begin{array}{l}\text { Economic and finan- } \\
\text { cial factors }\end{array}$ & $\begin{array}{l}\text { SWF equity allocation is not fully explained by } \\
\text { firm-level determinants. Other factors related } \\
\text { to diversification and natural endowments } \\
\text { (e.g., forest areas and fuel exports) partially } \\
\text { explain the shift in SWF equity investments } \\
\text { towards commodity and natural resource sec- } \\
\text { tors. }\end{array}$ \\
\hline $\begin{array}{l}\text { Are SWFs' investments } \\
\text { politically biased? A compar- } \\
\text { ison with mutual funds }\end{array}$ & $\begin{array}{l}\text { Avendano } \\
\text { and Santiso }\end{array}$ & 2009 & $\begin{array}{l}\text { Descriptive anal- } \\
\text { ysis }\end{array}$ & N/A & Political factors & $\begin{array}{l}\text { SWFs' and mutual funds's investments con- } \\
\text { verge when examining the political profile of } \\
\text { targeted countries. }\end{array}$ \\
\hline $\begin{array}{l}\text { Determinants of SWF cross- } \\
\text { border investments }\end{array}$ & $\begin{array}{l}\text { Megginson, } \\
\text { You and } \\
\text { Han }\end{array}$ & 2013 & $\begin{array}{l}\text { Cross-sectional } \\
\text { Tobit model }\end{array}$ & $\begin{array}{l}\text { Ratios based on the amount } \\
\text { invested by SWFs }\end{array}$ & $\begin{array}{l}\text { Economic, financial, } \\
\text { geographical and } \\
\text { cultural factors }\end{array}$ & $\begin{array}{l}\text { From the target country's perspective, high } \\
\text { levels of investor protection, strong economic } \\
\text { performance, and well-developed local capi- } \\
\text { tal markets attract higher levels of inbound } \\
\text { SWF investment. Moreover, SWFs are likely to } \\
\text { invest in countries that share the same cul- } \\
\text { ture, and investment values will be higher if } \\
\text { the bilateral trade between the acquirer and } \\
\text { target countries is higher. The results of this } \\
\text { study suggest that SWFs act as purely commer- } \\
\text { cial investors that facilitate cross-border corpo- } \\
\text { rate investment. }\end{array}$ \\
\hline $\begin{array}{l}\text { Determinants of SWF } \\
\text { investment in private equity } \\
\text { vs. public equity }\end{array}$ & $\begin{array}{l}\text { Johan, Knill } \\
\text { and Mauck }\end{array}$ & 2013 & Probit model & $\begin{array}{l}\text { Dummy variable equal to } 1 \text { if } \\
\text { the target firm is private, and } \\
0 \text { otherwise }\end{array}$ & $\begin{array}{l}\text { Financial, geographi- } \\
\text { cal and cultural } \\
\text { factors }\end{array}$ & $\begin{array}{l}\text { Cross-border investment by SWFs involves tar- } \\
\text { get nations where investor protection is low. } \\
\text { SWFs are more likely to invest in private equity } \\
\text { when the bilateral political relations between } \\
\text { the countries are low. Cultural differences are } \\
\text { positively related to the decision to invest in } \\
\text { private equity abroad. }\end{array}$ \\
\hline $\begin{array}{l}\text { Are SWFs contrarian } \\
\text { investors }\end{array}$ & $\begin{array}{l}\text { Ciarlone and } \\
\text { Miceli }\end{array}$ & 2014 & $\begin{array}{l}\text { Panel probit and } \\
\text { Tobit models }\end{array}$ & $\begin{array}{l}\text { Investment decision and the } \\
\text { share of equity investment in } \\
\text { country } j \text { at time } t \text { in total equity } \\
\text { investments by all SWFs at time } t\end{array}$ & $\begin{array}{l}\text { Economic, financial } \\
\text { and institutional } \\
\text { factors }\end{array}$ & $\begin{array}{l}\text { SWFs prefer to invest in countries with } \\
\text { a higher degree of economic development, } \\
\text { larger and more liquid financial markets, insti- } \\
\text { tutions that offer better protection of legal } \\
\text { rights, and a more stable macroeconomic envi- } \\
\text { ronment. }\end{array}$ \\
\hline
\end{tabular}

\section{Appendix 3. The two-tiered dynamic Tobit panel model}

For the two-tiered model, using Wooldridge's approach for initial conditions, the $c_{i j}$ are extended as follows. For the decision to invest, we have

$c_{i j}^{1}=d_{i j}+y_{i j, 0} \delta_{1}^{1} I_{i j, 0}\left(y_{i j, 0}>0\right)+\delta_{2}^{1} I_{i j, 0}\left(y_{i j, 0}=0\right)$

while for the amount to be invested,

$c_{i j}^{2}=d_{i j}+y_{i j, 0} \delta_{1}^{2} I_{i j, 0}\left(y_{i j, 0}>0\right)+\delta_{2}^{2} I_{i j, 0}\left(y_{i j, 0}=0\right)$ 
Using four different $\delta s$ allows for a better modelling of the influence of the initial conditions.

To estimate the model, Chang (2011b) proposes to maximize the log-likelihood function simulated through procedures based on a recursive algorithm formulated by the Geweke-Hajivassiliou-Keane simulator.

The simulated likelihood function with $R$ simulation draws based on the GHK simulator for country pair $i j$ can be obtained by combining Eqs. (5), (6), (11) and (12) as follows:

$L_{i j}=\frac{1}{R} \sum_{r=1}^{R} \prod_{t=1}^{T}\left[\frac{P^{(r)}\left(I_{i j, t}=1 \mid y_{i j, t-1}, d_{i j}, x_{i j, t}, \Theta_{1}\right)}{P^{(r)}\left(I_{i j, t}=1 \mid y_{i j, t-1}, d_{i j}, x_{i j, t}, \Theta_{2}\right)} f^{(r)}\left(y_{i j, t} \mid y_{i j, t-1}, d_{i j}, x_{i j, t}, \Theta_{2}\right)\right]^{I_{i j, t}} \times\left[P^{(r)}\left(I_{i j, t}=0 \mid y_{i j, t-1}, d_{i j}, x_{i j, t}, \Theta_{1}\right)\right]^{1-I_{i j, t}}$

where $\Theta_{1}=\left(\lambda_{1}^{1}, \lambda_{2}^{1}, \beta^{1}, \delta_{1}^{1}, \delta_{2}^{1}\right)$ and $\Theta_{2}=\left(\lambda_{1}^{2}, \lambda_{2}^{2}, \beta^{2}, \delta_{1}^{2}, \delta_{2}^{2}\right)$.

In all our model estimations, we used the number of simulations $R=120$, which is roughly the square root of the number of observations. Note that the two-tiered model would shrink to the conventional Tobit model (one-tiered model) when we restrict the two sets of parameters $\Theta_{1}=\Theta_{2} \cdot{ }^{24}$ For more implementation details about two-tiered dynamic Tobit model with the GHK simulator algorithm, please read Chang (2011b) and Xun and Lubrano (2016).

Appendix 4. Description of the variables

\begin{tabular}{|c|c|c|}
\hline Variable & Definition & Source \\
\hline SWF DUMMY & $\begin{array}{l}\text { Dummy variable that takes the value of one if there is at least one SWF investment in country } i \text { over the } \\
2000-2013 \text { period, and zero otherwise }\end{array}$ & \\
\hline SWF DEAL & $\begin{array}{l}\text { Number of deals in which the target is from country } i \text { and the acquirer is a Sovereign Wealth Fund from } \\
\text { country } j\end{array}$ & \\
\hline SWF AMOUNT & $\begin{array}{l}\text { Average value of the deals in which the target is from country } i \text { and the acquirer is a Sovereign Wealth } \\
\text { Fund from country }\end{array}$ & \\
\hline DIST & $\begin{array}{l}\text { Geographic distance in kilometers between the capital city of countries } i \text { and } j \text {. We obtained } \\
\text { the latitudes and longitudes of capital cities of each country and apply formula } 6378 \times \text { across }[ \\
\sin (\text { latAcquirer }) \times \sin (\text { latTarget })+\cos (\text { latAcquirer }) \times \cos [\text { (latTarget }) \times \cos (\text { lonTarget-lonAcquirer })] \text {, where } \\
\text { lat and lon are latitudes and longitudes, respectively (following the methodology of Knill et al. (2012)) }\end{array}$ & Maps of World \\
\hline GDP & $\begin{array}{l}\text { Difference in the Average Annual Real Growth Rate of the Gross Domestic Product from } 2000 \text { to } 2013 \\
\text { between the acquirer and target country. }\end{array}$ & $\begin{array}{l}\text { World Bank Development Indica- } \\
\text { tors }\end{array}$ \\
\hline INFLATION & $\begin{array}{l}\text { Difference in the Inflation Rate measured by the Consumer Price Index from } 2000 \text { to } 2013 \text { between the } \\
\text { acquirer and target country. }\end{array}$ & $\begin{array}{l}\text { World Bank Development Indica- } \\
\text { tors }\end{array}$ \\
\hline REER & $\begin{array}{l}\text { Real Effective Exchange Rates Based on the Annual Consumer Price Index considering } 41 \text { trading partners } \\
\text { from } 2000 \text { to 2013, taken as the difference between countries j and i. }\end{array}$ & Bruegel \\
\hline POLITY & $\begin{array}{l}\text { Polity score of the Polity IV Project that captures the level of authority of a regime, ranging from }-10 \\
\text { (hereditary monarchy) to } 10 \text { (consolidated democracy), taken as the difference between countries } \mathrm{j} \text { and } \mathrm{i} \text {. }\end{array}$ & Center for Systemic Peace \\
\hline KAOPEN & $\begin{array}{l}\text { Difference in the Normalized KAOPEN index between the acquirer and target country. Initially introduced } \\
\text { by Chinn and Ito (2006), this index measures a country's degree of capital account openness. Because } \\
\text { the index is not available for 2013, the values for this year have been estimated by the authors (linear } \\
\text { interpolation). As the index becomes higher, the country's degree of financial openness increases. }\end{array}$ & \\
\hline RELIGION & Dummy variable that is equal to 1 if countries $\mathrm{i}$ and $\mathrm{j}$ have the same predominant religion, and 0 otherwise. & CIA World Facebook \\
\hline GOV STAB & $\begin{array}{l}\text { Difference in the ICRG Government Stability index between the acquirer and target country. The ICRG } \\
\text { government stability index assesses both the ability of a country to carry out its declared program and } \\
\text { its ability to stay in office. The subcomponents are i) Government Unity; ii) Legislative Strength; and iii) } \\
\text { Popular Support. As the index increases, risk lowers (ranging from } 0 \text { to 12). }\end{array}$ & ICRG \\
\hline CORRUPTION & $\begin{array}{l}\text { Difference in the ICRG Corruption index between the acquirer and target country. The ICRG corruption } \\
\text { index assesses corruption within the political system. As the index increases, corruption lowers (ranging } \\
\text { from } 0 \text { to 6). }\end{array}$ & ICRG \\
\hline COMMODITY & $\begin{array}{l}\text { Dummy variable that is equal to } 1 \text { if the SWF's funds come from commodity revenues (oil, gas, and } \\
\text { minerals) and } 0 \text { otherwise. }\end{array}$ & $\begin{array}{l}\text { SWF Institute } \\
\text { SWFs' websites }\end{array}$ \\
\hline LARGE & $\begin{array}{l}\text { Dummy variable that is equal to } 1 \text { if the assets under an SWF's management are greater than USD } 100 \\
\text { billion, and } 0 \text { otherwise. }\end{array}$ & $\begin{array}{l}\text { SWF Institute } \\
\text { SWFs' websites }\end{array}$ \\
\hline POLITICIANS & $\begin{array}{l}\text { Dummy variable that is equal to } 1 \text { if there is at least one politician on the board of one of a country's } \\
\text { SWFs, and } 0 \text { otherwise. }\end{array}$ & $\begin{array}{l}\text { SWF Institute } \\
\text { SWFs' websites }\end{array}$ \\
\hline
\end{tabular}

\section{References}

Anderson, Van Wincoop, 2003. Gravity and gravitas: a solution to the border puzzle. Am. Econ. Rev. 93, 170-192.

Avendano, R., 2012. Sovereign Wealth Fund Investments: from Firm-level Preferences to Natural Endowments. Working paper. Paris School of Economics.

Avendaño, R., Santiso, J., 2009. Are Sovereign Wealth Funds' Investments Politically Biased? a Comparison with Mutual Funds. OECD Working paper, N. 283.

Bernstein, S., Lerner, J., Schoar, A., 2013. The investment strategies of sovereign wealth funds. J. Econ. Perspect. 27 (2), 219-238.

Catalano, A., 2009. Property Sector Is Well Placed to Attract Wealth of Nations (Sovereign wealth funds Special report, EG Capital).

Chang, S.-K., 2011a. A computationally practical robust simulation estimator for dynamic panel Tobit models. Stud. Nonlinear Dynam. Econom. 15 (4).
Chang, S.-K., 2011b. Simulation estimation of two-tiered dynamic panel tobit models with an application to the labor supply of married women. J. Appl. Econom. 26, 854-871.

Chhaochharia, V., Laeven, L., 2009. Sovereign Wealth Funds: Their Investment Strategies and Performance. Working Paper. International Monetary Fund.

Ciarlone, A., Miceli, V., 2014. Are Sovereign Wealth Funds Contrarian Investors? Banca d'Italia Working Paper N. 972.

Corden, W.M., Neary, J.P., 1982. Booming sector and de-industrialisation in a small open economy. Econ. J. 92 (368), 825-848.

Cragg, J., 1971. Some statistical models for limited dependent variables with application to the demand for durable goods. Econometrica 39 (5), 829-844.

Fernandez, D., Eschweiler, B., 2008. Sovereign Wealth Funds: a Bottom-up Primer. JP Morgan Research.

Heckman, J., 1979. Sample selection bias as a specification error. Econometrica 47, 153-162.

\footnotetext{
${ }^{24}$ The use of the GHK simulation is motivated by the requirement for estimating the random effect and the AR(1) error component.
} 
IMF, 2008. Sovereign Wealth Funds: a Work Agenda. IMF.

Johan, A., Knill, A.B., Mauck, N., 2013. Determinants of sovereign wealth fund investment in private versus public equity. J. Int. Bus. Stud. 44 (2), 155-172.

Kang, J.K., Kim, J.M., 2008. The geography of block acquisitions. J. Finance 63, 2817-2858.

Karolyi, G., Liao, R.C., 2017. State capitalism's global reach: evidence from foreign acquisitions by state-owned companies. J. Corp. Finance 42, 367-391.

Knill, A., Lee, B.-S., Mauck, N., 2012. Bilateral political relations and sovereign wealth fund investment. J. Corp. Finance 18 (1), 108-123.

Kotter, J., Lel, U., 2011. Friends or foes? Target selection decisions of sovereign wealth funds and their consequences. J. Financ. Econ. 101, 360-381.

Lyons, G., 2007. State Capitalism: the Rise of Sovereign Wealth Funds. Standard Charter Research.
Megginson, W.L., You, M., Han, L., 2013. Determinants of sovereign wealth fund cross-border investments. Financ. Rev. 148, 539-572.

Stulz, R., Williamson, R., 2003. Culture, openness and finance. J. Financ. Econ. 70, 313-349.

Wooldridge, J.M., 2005. Simple solutions to the initial conditions problem in dynamic, nonlinear panel data models with unobserved heterogeneity. J. Appl. Econom. 20 (1), 39-54.

Xun, Z., Lubrano, M., 2016. Simulation estimation of two-tiered dynamic panel tobit models with an application to the labour supply of married women: a comment. J. Appl. Econom. 31 (4), 756-761. 